\title{
Design and Synthesis of Reusable Nanoparticles for Reversible Chemisorption of Hexavalent Chromium Anions from Aqueous Media and Catalysis
}

\author{
Solomon Omwoma Lugasi \\ Department of Physical Sciences, Jaramogi Oginga Odinga University of Science and Technology, P.O. Box 210-40601, \\ Bondo, Kenya
}

Correspondence should be addressed to Solomon Omwoma Lugasi; solomwoma@yahoo.com

Received 17 April 2020; Revised 30 May 2020; Accepted 15 June 2020; Published 14 July 2020

Guest Editor: Tapan Sarkar

Copyright ( $) 2020$ Solomon Omwoma Lugasi. This is an open access article distributed under the Creative Commons Attribution License, which permits unrestricted use, distribution, and reproduction in any medium, provided the original work is properly cited.

A magnetically active nanocomposite material has been synthesized from the reaction mixture of magnetite core iron nanoparticles electrostatically coated with $\mathrm{SiO}_{2}$, hydrotalcite nanosheets $\left(\left[\mathrm{Eu}_{8}(\mathrm{OH})_{20}\left(\mathrm{H}_{2} \mathrm{O}\right)_{\mathrm{n}}\right]^{4+}\right)$, and decatungstophosphate anion $\left(\left[\alpha-\mathrm{PW}_{10} \mathrm{O}_{36}{ }^{7-}\right]\right)$. The resulting nanocomposite material, denoted as $\mathrm{Fe}_{3} \mathrm{O}_{4} @ \mathrm{SiO}_{2} @ \mathrm{LEuH} @ \mathrm{PW}_{10}$, is demonstrated to effectively adsorb chromate anions from aqueous solutions. The adsorption isotherms fit the Langmuir model with a capacity of $23 \mathrm{mmol} \cdot \mathrm{g}^{-1}$ after 42 minutes at $25^{\circ} \mathrm{C}$. The reaction is spontaneous at room temperature with $44.22 \mathrm{~kJ} \cdot \mathrm{mol}^{-1}$ of activation energy required. In addition, heating the chromate-adsorbed nanocomposite material at $40^{\circ} \mathrm{C}$ results in dissociation of the chromate anions from the nanocomposite material. As such, the recycled adsorbent $\mathrm{Fe}_{3} \mathrm{O}_{4} @ \mathrm{SiO}_{2} @ \mathrm{LEuH} @ \mathrm{PW}_{10}$ is reused for chromate removal in aqueous solutions for at least ten times without obvious loss of activity. This spontaneous reversible chemisorption mechanism for chromate adsorption provides a new pathway for separation and cleaning of industrial wastewater contaminated with chromate ions. The robust catalytic activity of the nanocomposite is also demonstrated.

\section{Introduction}

Chromium is used in various industrial activities such as electroplating, wood preservations, metallurgy, tanning, refractory materials, catalysis, dye, and pigment [1]. Chromium has unique properties such as anticorrosion, color, toxicity, heat resistivity, and high melting point that make it very difficult to replace in industry [2]. As such, the related industries generate large amounts of wastewater contaminated with chromium $[3,4]$.

Once in an aquatic environment, chromium exists in the form of trivalent or hexavalent species depending on the prevailing redox conditions [5]. The trivalent form $\left(\mathrm{Cr}^{3+}\right)$ adsorbs or precipitates as a solid (oxy)-hydroxide phase $[\mathrm{Cr}(\mathrm{OH})]^{2+}$ over the $\mathrm{pH}$ range of most natural waters [6]. In contrast, the hexavalent form, (Cr(VI)), exists as oxyacids in the $\mathrm{pH}$ range of most surface waters, where the primary hydrolyzed forms are chromic acid, hydrogen chromate ion, chromate ion, and dichromate ion [5,7].

The maximum set standard level for total chromium in drinking water is $0.1 \mathrm{ppm}$ and $\mathrm{Cr}(\mathrm{VI})$ is $0.05 \mathrm{ppm}$ [8]. Indeed, the set limit is high, and as a result, it is being reconsidered for revision based on the emerging toxicological effects of $\mathrm{Cr}(\mathrm{VI})$ [9]. Trivalent chromium is an essential micronutrient to plant and animal metabolism whereas $\mathrm{Cr}(\mathrm{VI})$ is carcinogenic and highly toxic to animals and plants at levels above $0.1 \mathrm{ppm}$, and it causes allergic dermatitis [10,11].

To date, the most adopted technology of $\mathrm{Cr}(\mathrm{VI})$ removal from wastewater involves its reduction to the trivalent form at $\mathrm{pH} 2$ and subsequent precipitation of $\mathrm{Cr}(\mathrm{OH})_{3}$ by increasing $\mathrm{pH}$ to $9 \sim 10$ using lime $[12,13]$. The disadvantages of such technology lie in the fact that (1) the reduction process produces large amounts of sludge. For example, $32 \mathrm{~kg}$ of 
sludge can be generated in order to remove $1 \mathrm{~kg}$ of $\mathrm{Cr}(\mathrm{VI})$ [14]; (2) the use of lime to precipitate the trivalent chromium makes the process complicated and more expensive.

Under such circumstances, a number of adsorbents such as activated carbon, lignocellulose, hydrotalcite, and mesoporous zirconium titanium oxides have been utilized for adsorption of the chromium species [5, 12, 15-17]. Nevertheless, similar problems of adsorbent disposal and cost implications still dominate. In addition, most $\mathrm{Cr}(\mathrm{VI})$ adsorbents reported so far use permanent physisorption mechanisms that do not allow reusability of adsorbents nor recovery of the $\mathrm{Cr}(\mathrm{VI})$ anions.

In terms of bacteria, fungi, algae, and different plants as adsorbents, they do show good adsorption capability in the laboratory [12]. The scale-up experiments by the application of these biological adsorbents into water treatments are not successful due to their relatively poor natural abundance [12]. Therefore, removal of $\mathrm{Cr}(\mathrm{VI})$ from wastewater still presents a great challenge in wastewater treatment technology.

Polyoxometalates (POMs) are a class of discrete anionic metal oxides of groups 5 and 6 and POMs exhibit attractive properties such as thermal and oxidative stability, remarkable electronic and magnetic properties, and Brønsted acidity, which result in intriguing applications ranging from medicine, catalysis to material science [18-21]. Recently, it was reported that the slow addition of $\mathrm{H}_{3} \mathrm{PW}_{12} \mathrm{O}_{40}$ to an aqueous solution of $\mathrm{K}_{2} \mathrm{CrO}_{4}$ at room temperature $(\mathrm{pH}=6.6 \pm 0.2)$ led to the formation of the final product $\mathrm{K}_{14}$ $\left[\mathrm{P}_{2} \mathrm{~W}_{20} \mathrm{O}_{72}\right] \cdot 24 \mathrm{H}_{2} \mathrm{O}$ (denoted as $\mathrm{P}_{2} \mathrm{~W}_{20}$ ) [22]. It was proposed that a $\mathrm{Cr}(\mathrm{VI})$-stabilized $\left[\mathrm{PW}_{10} \mathrm{O}_{36}\left(\mathrm{CrO}_{4}\right)_{2}\right]^{9-}$ intermediate was formed, which played a significant role in the formation of the $\mathrm{P}_{2} \mathrm{~W}_{20}$ cluster.

In other words, without the addition of $\mathrm{K}_{2} \mathrm{CrO}_{4}$ in the reaction mixture, the final product could not be obtained. Moreover, the $\mathrm{Cr}(\mathrm{VI})$-stabilized species of $\left[\mathrm{PW}_{10} \mathrm{O}_{36}\right.$ $\left.\left(\mathrm{CrO}_{4}\right)_{2}\right]^{9-}$ could dissociate upon the increase of temperature above $40^{\circ} \mathrm{C}$. Unfortunately, this intermediate was not isolated. However, the proposed intermediate shows the capability of $\mathrm{Cr}(\mathrm{VI})$ anions to chemically bond with $\mathrm{PW}_{10}$ anions. Therefore, a better understanding of the mechanism of reaction herein can be very beneficial for $\mathrm{Cr}(\mathrm{VI})$ removal from aqueous solutions provided that the $\left[\mathrm{PW}_{10} \mathrm{O}_{36}\right]^{7-}$ (denoted as $\mathrm{PW}_{10}$ ) [23] cluster is heterogenized.

In this contribution, a report on the isolation of the abovementioned intermediate by electrostatic immobilization of $\left[\mathrm{PW}_{10} \mathrm{O}_{36}\right]^{7-}$ anions onto the surface of $\mathrm{Fe}_{3} \mathrm{O}_{4} @$ $\mathrm{SiO}_{2} @ \mathrm{LEuH}\left(\mathrm{LEuH}\right.$ represents $\left.\left[\mathrm{Eu}_{8}(\mathrm{OH})_{5}\left(\mathrm{H}_{2} \mathrm{O}\right)_{\mathrm{n}}\right]^{4+}\right)$ is presented (Figure 1). The core magnetite iron nanoparticles coated with silica $[24,25]$ are electrostatically interacted with the layered rare-earth hydroxide nanosheets of LEuH (Figure 2) [26-28]. The resulting nanocomposite material of $\mathrm{Fe}_{3} \mathrm{O}_{4} @ \mathrm{SiO}_{2} @ \mathrm{LEuH} @ \mathrm{PW}_{10}$ is able to sorb chromate anions efficiently from aqueous solution (Figure 3 ). And the chromate anions can further dissociate from the absorbed composite material by applying heat above $40^{\circ} \mathrm{C}$, leading to the release of the original $\mathrm{Fe}_{3} \mathrm{O}_{4} @ \mathrm{SiO}_{2} @ \mathrm{LEuH} @ \mathrm{PW}_{10}$. As a result, the magnetically active nanocomposite material can be recycled and reused for $\mathrm{Cr}(\mathrm{VI})$ removal for at least ten times without obvious loss of activity. Scale-up experimental results indicate that the magnetically active nanocomposite material of $\mathrm{Fe}_{3} \mathrm{O}_{4} @ \mathrm{SiO}_{2} @ \mathrm{LEuH} @ \mathrm{PW}_{10}$ (Figure 1) is efficient for $\mathrm{Cr}(\mathrm{VI})$ removal. Therefore, such reversible chemisorption process provides a new pathway for the $\mathrm{Cr}(\mathrm{VI})$ removal from industrial wastewater.

In order to prove that the $\mathrm{PW}_{10}$ anions do not dissociate into its individual elements during the nanoparticle synthesis, a catalytic experiment synonymous with POMs is done. Under which phenol red is catalysed to bromophenol blue using $\mathrm{Fe}_{3} \mathrm{O}_{4} @ \mathrm{SiO}_{2} @ \mathrm{LEuH} @ \mathrm{PW}_{10}$ nanocomposite material as a catalyst.

\section{Materials and Methods}

2.1. Chemical Materials. Analytically pure $\mathrm{KOH}, \mathrm{NaOH}$, $\mathrm{Na}_{2} \mathrm{WO}_{4}, \mathrm{CH}_{3} \mathrm{COONa}, \mathrm{H}_{2} \mathrm{WO}_{3}, \mathrm{Eu}_{2} \mathrm{O}_{3}, \mathrm{FeCl}_{3}, \mathrm{H}_{3} \mathrm{PO}_{4}, \mathrm{HCl}$, $\mathrm{H}_{2} \mathrm{SO}_{4}, \mathrm{CsOH}$, ethanol, methanol, ammonium solution, ethylene glycol, and tetraethyl orthosilicate were purchased from Alfa Aesar and used without further purification. The syntheses of the decatungstophosphate anion $\left(\left[\alpha-\mathrm{PW}_{10} \mathrm{O}_{36}\right]\right.$ $\left.{ }^{7-}\right)$ [23], layered europium hydroxide $\left(\mathrm{Eu}_{2}(\mathrm{OH})_{5} \mathrm{Cl} \cdot \mathrm{nH}_{2} \mathrm{O}\right)$ [26] (LEuH-Cl), and silicon-coated magnetic iron nanoparticles of $\mathrm{Fe}_{3} \mathrm{O}_{4} @ \mathrm{SiO}_{2}$ nanospheres [24] were synthesized and characterized according to literature methods.

2.2. Characterization. Powder X-ray diffraction (XRD) patterns were recorded on a Rigaku XRD-6000 diffractometer under the following conditions: $40 \mathrm{kV}, 30 \mathrm{~mA}, \mathrm{Cu}-$ Ka radiation $(\lambda=0.154 \mathrm{~nm})$, scan step of $0.01^{\circ}$, and scan range between $3^{\circ}$ and $80^{\circ}$. Fourier transform infrared (FTIR) spectra were recorded on a Bruker Vector 22 infrared spectrometer, using the $\mathrm{KBr}$ pellet method. Scanning electron microscopy (SEM) images and energy-dispersive X-ray spectroscopy (EDX) analytical data were obtained using a Zeiss Supra 55 SEM equipped with an EDX detector.

Transmission electron microscopy (TEM) micrographs were recorded using a Hitachi $\mathrm{H}-800$ instrument. Inductively coupled plasma-atomic emission spectroscopy (ICPAES) analysis was performed using a Shimadzu ICPS-7500 spectrometer after a weighed amount was dissolved in $\mathrm{HCl}$ solution. The fluorescence emission spectra were recorded with a Hitachi F-7000 fluorospectrometer with a Xe lamp as the excitation source.

The UV absorption measurements were performed with a TU-1901 UV/Vis spectrophotometer with $1 \mathrm{~nm}$ optical resolution over the range of $190-900 \mathrm{~nm}$. The specific surface area determination and pore volume and size analysis were performed by Brunauer-EmmettTeller (BET) and Barrett-Joyner-Halenda (BJH) methods, respectively, by use of a Quantachrome Autosorb-1C-VP analyzer. Prior to the measurements, the samples were degassed at $100^{\circ} \mathrm{C}$ for $6 \mathrm{~h}$. The $\mathrm{OH}$ content was obtained by neutralization back-titration after the sample had been dissolved in $0.1 \mathrm{~N}$ standard $\mathrm{H}_{2} \mathrm{SO}_{4}$. Thermogravimetric analysis was carried out on a locally produced HCT thermal analysis system in flowing $\mathrm{N}_{2}$ with a heating rate of $10^{\circ} \mathrm{C} \cdot \mathrm{min}^{-1}$. 


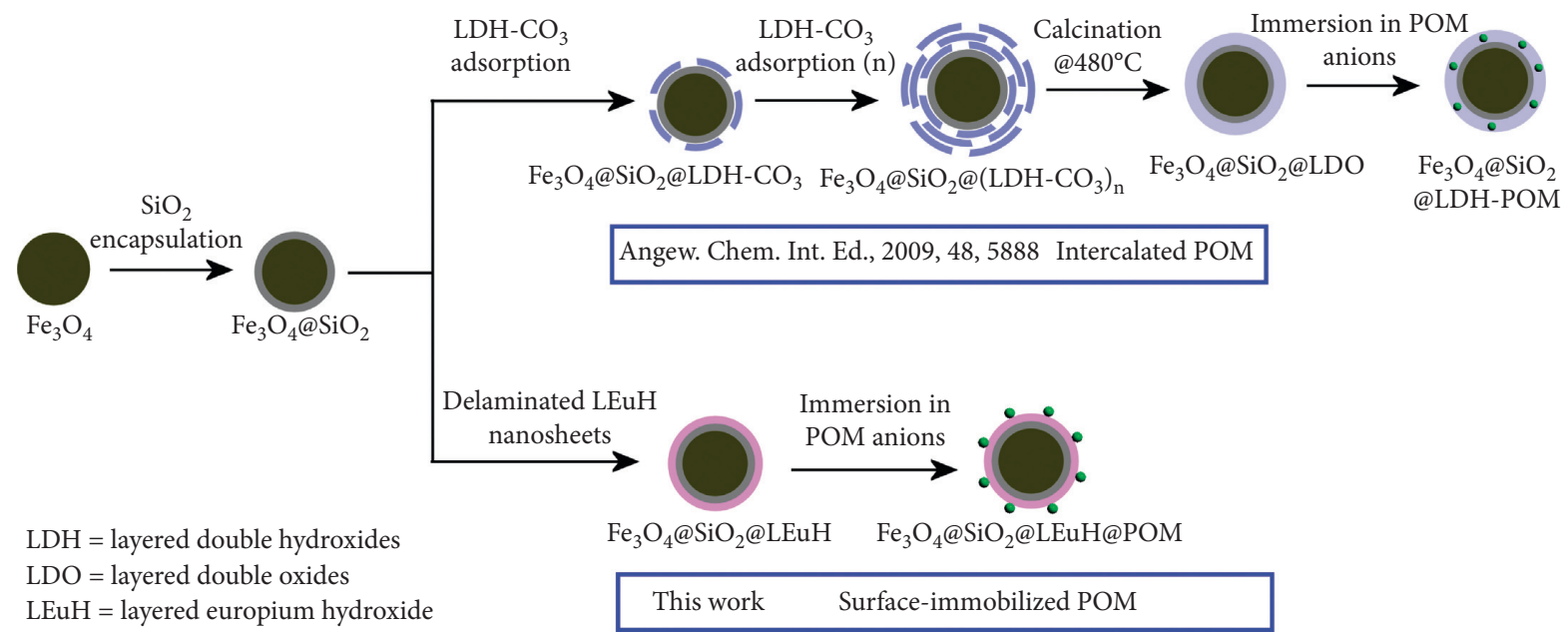

FIGURE 1: Comparisons between the new proposed synthetic pathway of fabricating layered rare-earth hydroxide nanosheets with POMs and literature method.


FIgURE 2: Proposed synthetic pathway of preparing $\mathrm{Fe}_{3} \mathrm{O}_{4} @ \mathrm{SiO}_{2} @ \mathrm{LEuH} @ \mathrm{PW}_{10}$ nanocomposite material; water molecules avoided for clarity.

2.3.Preparation of $\mathrm{Fe}_{3} \mathrm{O}_{4} @ \mathrm{SiO}_{2} @ L E u H @ P W_{10}$ Nanocomposite. $\mathrm{Fe}_{3} \mathrm{O}_{4} @ \mathrm{SiO}_{2}(0.1 \mathrm{~g})$ was dispersed in deionized water under sonication. LEuH nanosheets were prepared by ultrasonicating freshly prepared $\mathrm{LEuH}(0.2 \mathrm{~g})$ in aqueous media for $10 \mathrm{~min}$ to delaminate the positively charged nanosheets, followed by centrifugation at $2000 \mathrm{rpm}$ to remove undelaminated material. The resultant delaminated nanosheets of $\mathrm{LEuH}(0.05 \mathrm{~g})$ were added dropwise to the above-prepared $\mathrm{Fe}_{3} \mathrm{O}_{4} @ \mathrm{SiO}_{2}$.

The mixture was stirred at room temperature (RT) for 12 hours, separated by a magnet, and washed several times with deionized water and this procedure was repeated 5 times to get the $\mathrm{Fe}_{3} \mathrm{O}_{4} @ \mathrm{SiO}_{2} @ \mathrm{LEuH}$ brown material.

The wet sample of $\mathrm{Fe}_{3} \mathrm{O}_{4} @ \mathrm{SiO}_{2} @ \mathrm{LEuH}(0.11 \mathrm{~g})$ was dispersed in deionized water $(50 \mathrm{ml})$ under sonication for 10 min. The sonicated $\mathrm{Fe}_{3} \mathrm{O}_{4} @ \mathrm{SiO}_{2} @ \mathrm{LEuH}$ was transferred into a beaker and $\mathrm{Cs}_{7}\left[\mathrm{PW}_{10} \mathrm{O}_{36}\right](5 \mathrm{~g})$, prepared by dispersion in deionized water $(40 \mathrm{ml})$ under sonication for $10 \mathrm{~min}$, was added dropwise as the contents were stirred at RT overnight. The desired $\mathrm{Fe}_{3} \mathrm{O}_{4} @ \mathrm{SiO}_{2} @ \mathrm{LEuH} @ \mathrm{PW}_{10}$ material was washed several times with deionized water before being dried at $40^{\circ} \mathrm{C}$ for 12 hours to obtain a brown powder $(0.018 \mathrm{~g})$. 


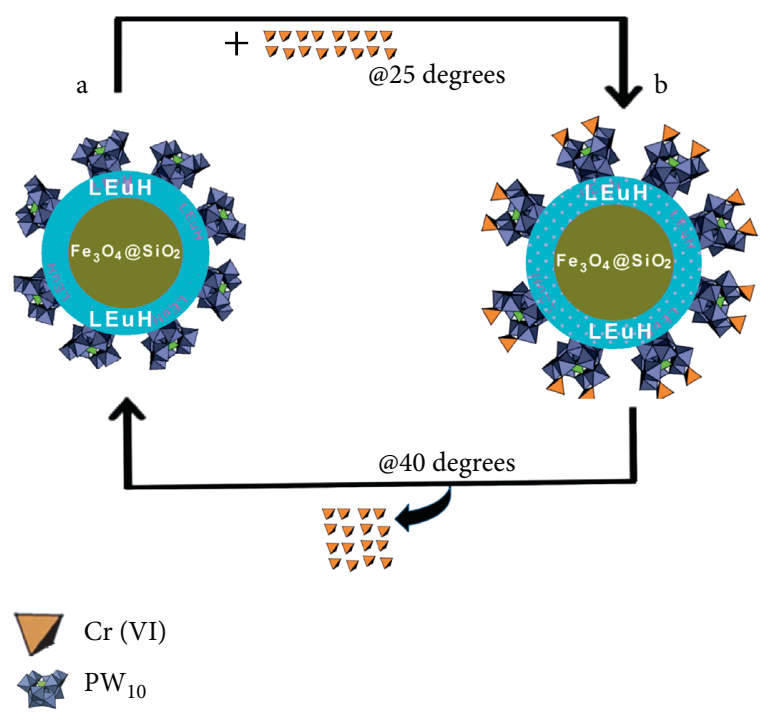

FIGURE 3: Proposed adsorption processes of $\mathrm{Fe}_{3} \mathrm{O}_{4} @ \mathrm{SiO}_{2} @ \mathrm{LEuH} @$ $\mathrm{PW}_{10}$ adsorbent with hexavalent chromium anions.

2.4. Adsorption Experiments. The $\mathrm{Fe}_{3} \mathrm{O}_{4} @ \mathrm{SiO}_{2} @ \mathrm{LEuH} @$ $\mathrm{PW}_{10}$ nanocomposite material was used to remove $\mathrm{Cr}(\mathrm{VI})$ anions from deionized water, laboratory tap water, and municipal wastewater. For deionized water and tap water, a known concentration of $\mathrm{Cr}(\mathrm{VI})$ anions was introduced into the water sample and the nanocomposite $(0.4 \mathrm{~g})$ was added. Then, the test solution was kept stirring for 1 hour. After that, the nanocomposite was separated by a magnet and the water was tested for $\mathrm{Cr}(\mathrm{VI})$ using EPA method 218.7.

For the municipal wastewater, a known concentration of $\mathrm{Cr}(\mathrm{VI})$ was introduced into the sampled water in Teflon bottles and left to acclimatize to the sample collection ambient environment. After two days, the wastewater was filtered and treated with the nanoparticles as indicated above and the concentration of $\mathrm{Cr}(\mathrm{VI})$ determined using EPA method 218.7. The separated nanoparticles after the experiments were heated at $40^{\circ} \mathrm{C}$ in a small amount of aqueous solution for 30 minutes to yield a concentrated chromate anion solution and the adsorbent was reused ten times. The chromate anions were recovered by adding stoichiometric amounts of $\mathrm{KOH}$ solution to the solution to yield potassium chromate powder after solvent evaporation.

\subsection{Kinetic Studies}

2.5.1. Determination of Adsorption Rate and Equilibrium. Ten samples of deionized water $(100 \mathrm{ppm})$ solutions were treated with $0.2 \mathrm{~g}$ of $\mathrm{Fe}_{3} \mathrm{O}_{4} @ \mathrm{SiO}_{2} @ \mathrm{LEuH} @ \mathrm{PW}_{10}$ nanocomposite for $0,10,20,30,40,50,60,80,100$, and 150 minutes. After each experiment, the magnetic nanocomposite was separated and the deionized water tested for $\mathrm{Cr}(\mathrm{VI})$ concentration.

2.5.2. Adsorption Isotherms. The $\mathrm{Fe}_{3} \mathrm{O}_{4} @ \mathrm{SiO}_{2} @ \mathrm{LEuH} @$ $\mathrm{PW}_{10}$ nanocomposite $(0.2 \mathrm{~g})$ was stirred with $50 \mathrm{ml}$ solutions having different concentrations $(1,5,10,20,50,100,200$, $300,400,500$, and $1000 \mathrm{ppm}$ ) for one hour to insure equilibrium. The magnetic nanocomposite was separated and the resulting aqueous solutions tested for $\mathrm{Cr}(\mathrm{VI})$ concentration. The amount of $\mathrm{Cr}(\mathrm{VI})$ up taken per gram of the nanoparticles $(q)$ was determined according to equation (1), in which $C o$ is the initial $\mathrm{Cr}(\mathrm{VI})$ concentration, $C$ is the concentration of the equilibrated final solution, $V$ is the volume of the aqueous phase, and $m$ is the mass of the nanoparticles in the system:

$$
q=\frac{\left(C_{0}-C\right) V}{m}
$$

The optimized reaction temperature and $\mathrm{pH}$ for the nanocomposite with $\mathrm{Cr}(\mathrm{VI})$ anions were determined by reacting the $\mathrm{Fe}_{3} \mathrm{O}_{4} @ \mathrm{SiO}_{2} @ \mathrm{LEuH} @ \mathrm{PW}_{10}$ nanocomposite $(0.2 \mathrm{~g})$ with $50 \mathrm{ml}$ of $\mathrm{Cr}(\mathrm{VI})$ solution $(100 \mathrm{ppm})$ at different temperatures and $\mathrm{pH}$. The $\mathrm{pH}$ was adjusted by $0.1 \mathrm{~N} \mathrm{HCl}$ or diluted by $\mathrm{NaOH}$ solutions, respectively.

\subsection{Determination of $\mathrm{Cr}(\mathrm{VI})$ Concentration}

2.6.1. Preparation of Reagents. The DPC reagent, $2 \mathrm{mM}$ of 1,5-diphenylcarbazide in $10 \%$ methanol and $0.5 \mathrm{M}(1 \mathrm{~N})$ sulfuric acid, was prepared from the following solutions [29]. Solution A: $100 \mathrm{~mL}$ of methanol was added to 0.50 gram of 1,5-diphenylcarbazide, and the mixture was sonicated for five minutes to dissolve the solid. Solution B: $28 \mathrm{~mL}$ of sulfuric acid was added to $500 \mathrm{~mL}$ of deionized water in $1 \mathrm{~L}$ beaker, and the solution was cooled to room temperature. Then, Solution A was added to Solution B and it was diluted to $1 \mathrm{~L}$. The solution was used for the determination of the absorption amount of $\mathrm{Cr}(\mathrm{VI})$ anions.

2.6.2. Preparation of Standard Cr(VI) Solutions and Measurement of Unknown Sample Concentration. $\mathrm{K}_{2} \mathrm{CrO}_{4}$ was dried at $100^{\circ} \mathrm{C}$ to a constant weight for 12 hours. Then, $0.283 \mathrm{~g}$ of $\mathrm{K}_{2} \mathrm{CrO}_{4}$ was dissolved in deionized water and diluted to $100 \mathrm{~mL}$. The stock solution containing $1000 \mu \mathrm{g} / \mathrm{mL}$ or $1000 \mathrm{ppm}$ was stored at room temperature. A series of calibration standards were prepared by diluting the stock solution using deionized water. The calibration standards were used to generate a standard curve (Figure 4) and unknown sample concentrations determined by the UV/Vis spectrophotometer (TU-1901 UV/Vis spectrophotometer) from the standard curve at $530 \mathrm{~nm}$. Both standard solutions and samples were treated by DPC before analysis. In a typical procedure, $10 \mathrm{~mL}$ of the test solution was treated with $1 \mathrm{~mL}$ of DPC before UV analysis at $530 \mathrm{~nm}$ using the external standard method.

2.7. Method Detection Limit Determination. The standard deviations of seven samples containing $0.005 \mathrm{ppm}$ $\mathrm{K}_{2} \mathrm{CrO}_{4}$ were determined. The half range for the prediction interval of results (HRPIR) was determined using the following equation: HRPIR $=3.963 S$, where $S$ is the standard deviation and 3.963 is a constant value for seven replicates. The upper and lower limits for the prediction 




FIGURE 4: The external UV standard curve used in determining $\mathrm{Cr}(\mathrm{VI})$ concentrations in test solutions at $530 \mathrm{~nm}$ wavelength.

interval of the results were tested using the following equation:

$$
\frac{\text { mean }+ \text { HRPIR }}{\text { fortified concentration }} \times 100 \leq 150 \%,
$$

and the lower prediction interval results were calculated as follows:

$$
\frac{\text { mean }+ \text { HRPIR }}{\text { fortified concentration }} \times 100 \geq 50 \% \text {. }
$$

The results of 0.0148 (148\%) for upper limit and 0.0047 (47\%) for lower limit allowed the acceptance of the chosen detection limit. Subsequently, the detection limit was determined using the following equation:

$$
\mathrm{DL}=S \times t(n-1), \quad 1-\alpha=0.99,
$$

where DL is the detection limit, $t$ is Student's $t$-test value, $n$ is the number of replicates, $S$ is the standard deviation of replicate analyses, and $\alpha$ is the replicated samples that have been done. $1-\alpha$ is the degree of freedom [30]. The detection limit was determined to be $0.002 \times 3.963=0.007 \mathrm{ppm}$.

\section{Results and Discussion}

3.1. Adsorbent Characterization. As shown in Figure 5(a), SEM images of LEuH-Cl exhibit plate-like morphology with $200 \mathrm{~nm}$ (length) $\times 100 \mathrm{~nm}$ (width). HRTEM images of the delaminated LEuH nanosheets (Figure 5(b)) clearly show the platelet morphology. The selected area electron diffraction pattern (SAED) taken from an individual delaminated nanoplate lying on a copper grid shows the well-ordered diffraction (Figure 5(c)), indicating the formation of the superlattice structure. The brighter spots correspond to a fundamental cell in a pseudohexagonal symmetry $\left(a_{f}=3.7 \AA\right)$. Therefore, we can calculate $d_{100}=2 \sqrt{ } 3 a_{f}=$ $12.81 \AA$ and $d_{010}=2 a_{f}=7.4 \AA$. The fundamental cell indicates a hexagonal arrangement of Eu-Eu atoms closely related to a LDH-like host layer (Eu-Eu: $3.7 \AA$ ) (Figure 5(c)). These results have been further confirmed by XRD measurements (Figure 6), and they are in agreement with the literature [28].
Hence, the delaminated nanosheets have been assumed to have the formula $\left[\mathrm{Eu}_{8}(\mathrm{OH})_{20} \cdot \mathrm{nH}_{2} \mathrm{O}\right] \mathrm{Cl}_{4}(\mathrm{LEuH})$ in accordance with the intensive characterization of these materials in [28].

The delaminated $\mathrm{LEuH}$ nanosheets have been applied to immobilize $\left[\mathrm{PW}_{10} \mathrm{O}_{36}\right]^{7-}$ anions onto $\mathrm{Fe}_{3} \mathrm{O}_{4} @ \mathrm{SiO}_{2}$ magnetite nanospheres to obtain a new nanocomposite material of $\mathrm{Fe}_{3} \mathrm{O}_{4} @ \mathrm{SiO}_{2} @ \mathrm{LEuH} @ \mathrm{PW}_{10}$. Note that the $\mathrm{C}_{7} \mathrm{PW}_{10} \mathrm{O}_{36}$ $\mathrm{POM}$ salt used is insoluble in water, and hence, by washing the desired product several times with water, all the nonimmobilized $\mathrm{PW}_{10}$ anions are washed away. We did not perform any experiments that would show if the immobilization is achieved through ionic exchange of POMs and $\mathrm{Cl}^{-}$ on the LEuH nanosheets or by electrostatic interactions. However, XPS spectroscopy of $\mathrm{Fe}_{3} \mathrm{O}_{4} @ \mathrm{SiO}_{2} @ \mathrm{LEuH} @ \mathrm{PW}_{10}$ (Figure 7) shows the existence of the starting materials in their original oxidation states. The peaks were fitted to specific oxidation status of individual elements using the mixed Gaussian-Lorentzian function, which is a nonlinear squares fitting algorithm, and Shirley-type background subtraction that uses XPS peak fit software [31]. The binding energies of $\mathrm{Eu}_{3 \mathrm{~d}}$ are recorded at $1135 \mathrm{eV}$, while the $\mathrm{W}_{4 \mathrm{f}}$ doublet $\left(\mathrm{W}_{4} \mathrm{f}_{7 / 2}\right.$ and $\mathrm{W}_{4} \mathrm{f}_{5 / 2}$ ) can be observed at 35.7 and $37.8 \mathrm{eV}$, corresponding to the hexavalent state of $\mathrm{W}^{6+}$ [32]. Thus, the binding energies of $\mathrm{Eu}^{3+}$ and $\mathrm{W}^{6+}$ do not change after the fabrication of the nanocomposite material of $\mathrm{Fe}_{3} \mathrm{O}_{4} @ \mathrm{SiO}_{2} @ \mathrm{LEuH} @ \mathrm{PW}_{10}$.

The XRD diffraction patterns clearly show the existence of peaks from $\mathrm{LEuH}$ and $\mathrm{Fe}_{3} \mathrm{O}_{4} @ \mathrm{SiO}_{2}$ starting materials in addition to other peaks that might arise out of the immobilized POM anions (Figure 8).

In the FT-IR spectra of $\mathrm{Fe}_{3} \mathrm{O}_{4} @ \mathrm{SiO}_{2} @ \mathrm{LEuH} @ \mathrm{PW}_{10}$ (Figure 9), the two stretching bands at $1093 \mathrm{~cm}^{-1}$ and $1045 \mathrm{~cm}^{-1}$ can be due to the $\mathrm{P}-\mathrm{O}$ stretching, while the bands at 943,875 , and $793 \mathrm{~cm}^{-1}$ are attributed to asymmetric stretching of the $\mathrm{W}-\mathrm{O}_{\mathrm{d}}$ bond $\left(\mathrm{O}_{\mathrm{d}}\right.$ is the terminal oxygen), $\mathrm{W}-\mathrm{O}_{\mathrm{b}}-\mathrm{W}$ bridge $\left(\mathrm{O}_{\mathrm{b}}\right.$ is the bridging oxygen that links two corner-sharing octahedron), and asymmetric stretching of the $\mathrm{W}-\mathrm{O}_{\mathrm{c}}-\mathrm{W}\left(\mathrm{O}_{\mathrm{c}}\right.$ is the bridging oxygen that links two edgesharing octahedron), respectively [23]. Compared with the vibration bands of $\mathrm{Fe}_{3} \mathrm{O}_{4} @ \mathrm{SiO}_{2}$ and $\mathrm{Cs}_{7} \mathrm{PW}_{10} \mathrm{O}_{36}$ (Figure 9), most of the stretching bands in the FT-IR spectrum of $\mathrm{Fe}_{3} \mathrm{O}_{4} @ \mathrm{SiO}_{2} @ \mathrm{LEuH} @ \mathrm{PW}_{10}$ overlap.

SEM images of the $\mathrm{Fe}_{3} \mathrm{O}_{4} @ \mathrm{SiO}_{2} @ \mathrm{LEuH} @ \mathrm{PW}_{10}$ nanocomposite exhibit well-dispersed spherical morphology with energy-dispersive X-ray spectroscopy elemental mapping (EDX) results for tungstate shown (Figure 10). Although HRTEM images of the $\mathrm{Fe}_{3} \mathrm{O}_{4} @$ $\mathrm{SiO}_{2} @ \mathrm{LEuH} @ \mathrm{PW}_{10}$ nanocomposite show core-shell structures, the SAED pattern of the $\mathrm{Fe}_{3} \mathrm{O}_{4} @ \mathrm{SiO}_{2} @ \mathrm{LEuH} @$ $\mathrm{PW}_{10}$ nanocomposite exhibits the atoms organized in a tetragonal symmetry, which is in good contrast to that by $\mathrm{Fe}_{3} \mathrm{O}_{4} @ \mathrm{SiO}_{2}$ (Figure 11). Moreover, the EDX results clearly indicate the presence of the desired elements in the as-synthesized materials.

Other characterization done includes BET (Figure 12). It is important to note that the abrupt rise near $P / P_{o}=1$ in the BET experiments is due to the pores within the nanocomposite material and not on the surface of the 

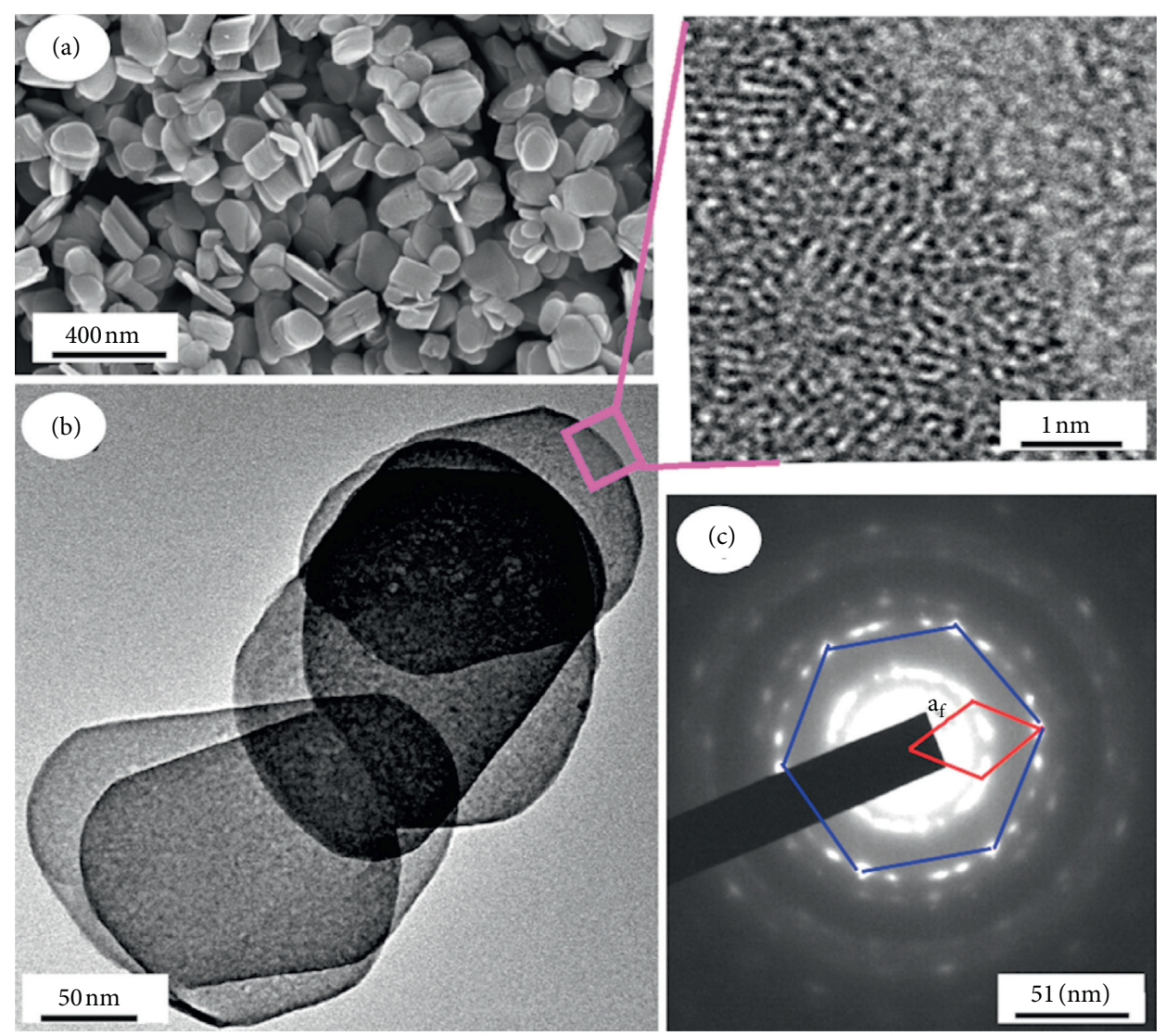

FIGURE 5: (a) SEM image of LEuH-Cl; (b) HRTEM of delaminated LEuH nanosheets, inset: a higher magnification at the edge of a single plate lying on a copper grid. (c) SAED pattern taken from an individual plate lying on a copper grid.

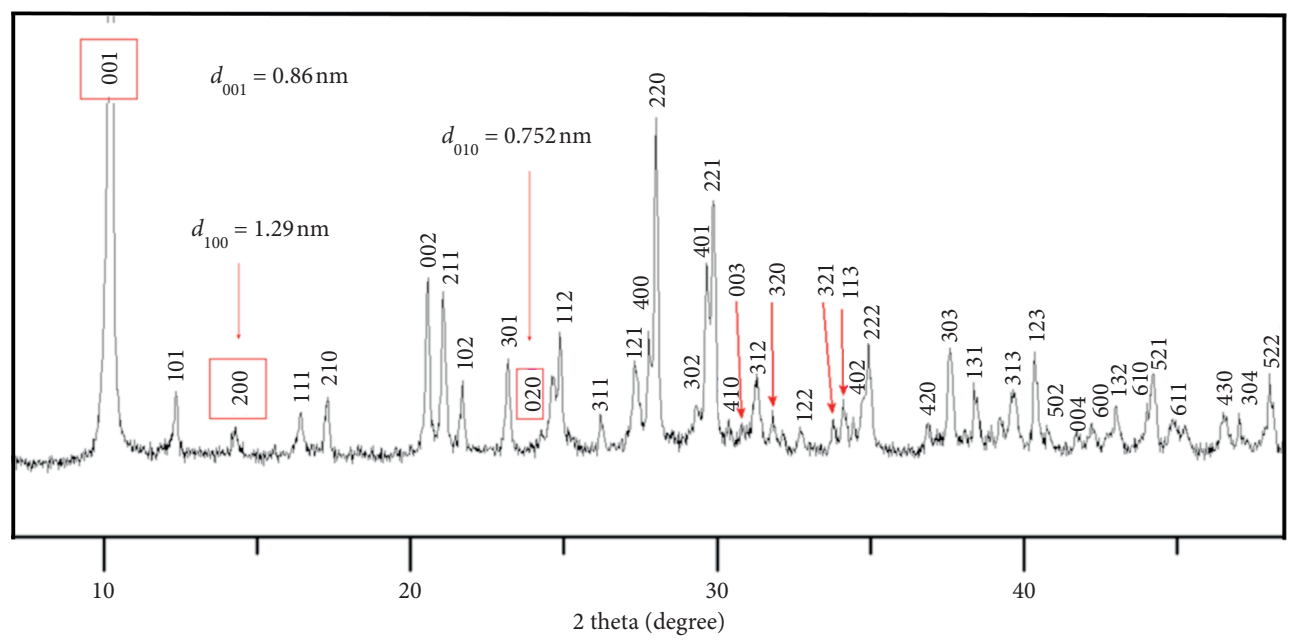

Figure 6: XRD diffraction patterns of LEuH-Cl $\left[\mathrm{Eu}_{2}(\mathrm{OH})_{5} \mathrm{Cl} \cdot \mathrm{H}_{2} \mathrm{O}\right]$.

nanomaterial. This is particularly true as such pores would otherwise be visible in the SEM images shown in Figure 10.

Thermogravimetric curves (Figure 13) reveal three distinct weight losses. The initial weight loss below $150^{\circ} \mathrm{C}$ is due to the removal of interlayer water, and the amount can be determined from the weight loss below $150^{\circ} \mathrm{C}$ to be 3 for $\mathrm{Fe}_{3} \mathrm{O}_{4} @ \mathrm{SiO}_{2} @ \mathrm{LEuH}_{10} @ \mathrm{PW}_{10}$. The second weight loss from around $150^{\circ} \mathrm{C}$ to $300^{\circ} \mathrm{C}$ is attributed to the loss of water from the condensation of hydroxyl groups. The next step above $400^{\circ} \mathrm{C}$ should involve the loss of $\mathrm{Cl}$ anions.

3.2. Hexavalent Chromium Adsorption Results. The adsorption of $\mathrm{Cr}(\mathrm{VI})$ anions in aqueous media using the

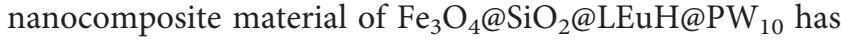
been investigated. After the adsorption experiments, the 




(a)

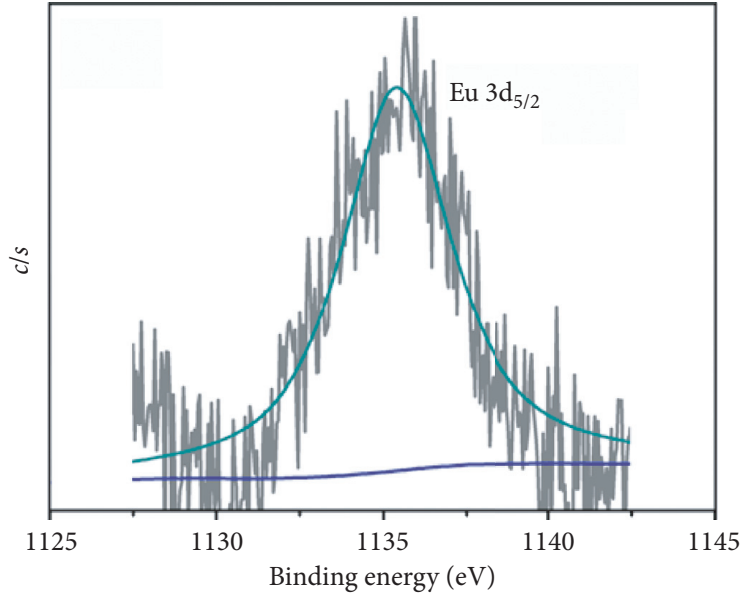

(b)



(c)

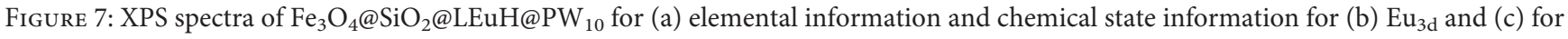
$\mathrm{W}_{4 \mathrm{f}}$.
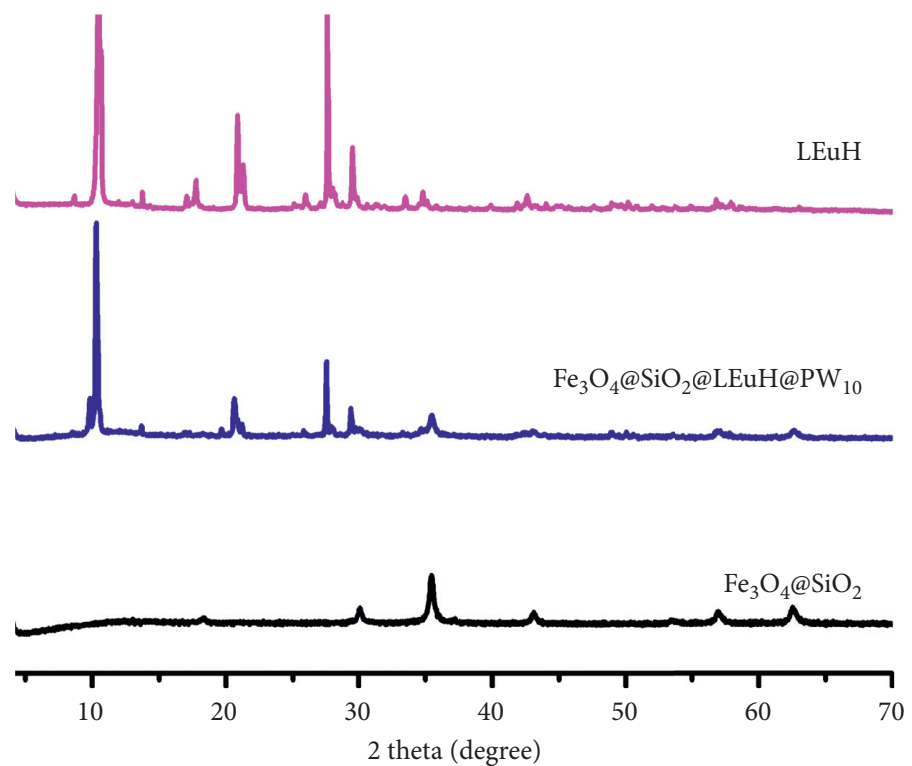

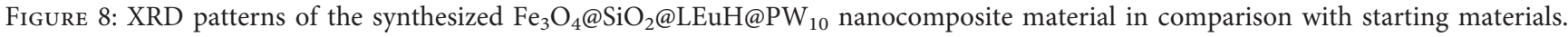




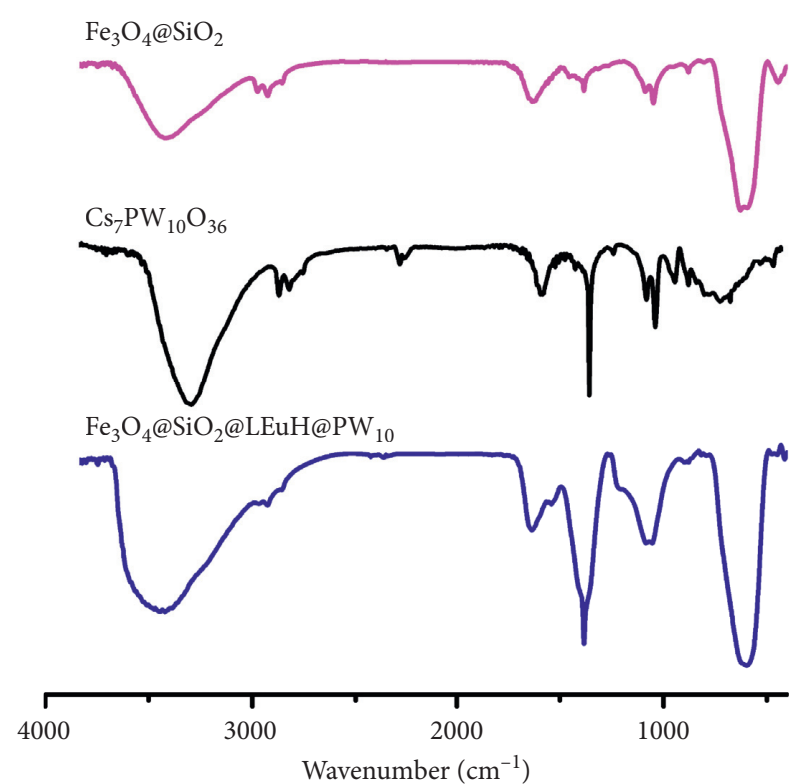

FIgURE 9: FT-IR spectra of the synthesized $\mathrm{Fe}_{3} \mathrm{O}_{4} @ \mathrm{SiO}_{2} @ \mathrm{LEuH} @$ $\mathrm{PW}_{10}$ nanoparticles in comparison with starting materials.
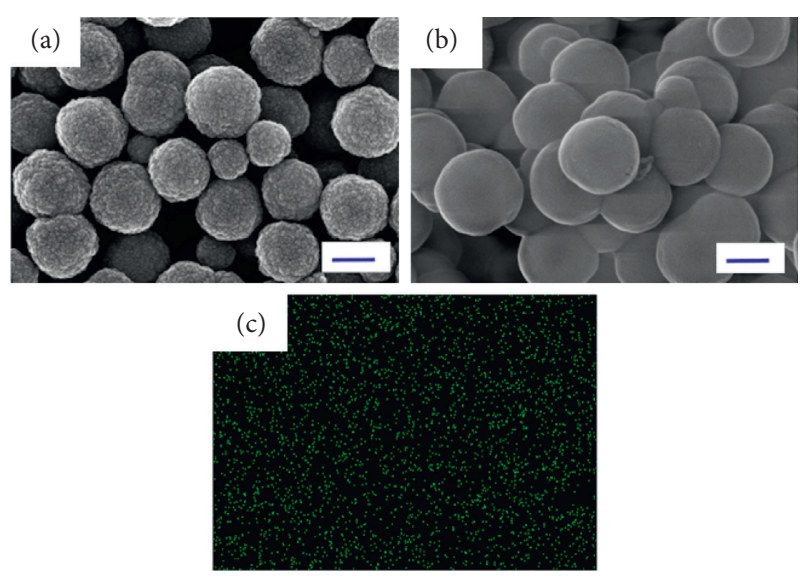

Figure 10: SEM images of (a) $\mathrm{Fe}_{3} \mathrm{O}_{4} @ \mathrm{SiO}_{2}$ and (b) $\mathrm{Fe}_{3} \mathrm{O}_{4} @ \mathrm{SiO}_{2} @$ LEuH@PW 10 and (c) EDX metal mapping for W (all the scale bars are $200 \mathrm{~nm}$ ).

resultant filtrate is derivatized with 1,5-diphenylcarbazide in order to detect $\mathrm{CrO}_{4}{ }^{2-}$ at a wavelength of $530 \mathrm{~nm}$ (Figure 14). The results show a complete adsorption of the chromate anions from the deionized water (Figure 14(c)). For tap water and municipal wastewater samples, the nanocomposite material adsorbs the chromate anions to undetectable limits (denoted as ND, Table 1). Scale-up experiments using the nanocomposite material for $\mathrm{Cr}(\mathrm{VI})$ removal in $0.5 \mathrm{~L}$ of water show complete adsorption of $\mathrm{Cr}(\mathrm{VI})$ to a nondetectable limit, indicating a great potential for the application of such magnetically active $\mathrm{Fe}_{3} \mathrm{O}_{4} @ \mathrm{SiO}_{2} @$ LEuH@PW 10 material.

Heating the adsorbed composite material, $\mathrm{Fe}_{3} \mathrm{O}_{4} @$ $\mathrm{SiO}_{2} @ \mathrm{LEuH} @ \mathrm{PW}_{10} \mathrm{Cr}_{2}$, at $40^{\circ} \mathrm{C}$ in aqueous solution yields a concentrated chromate anion solution, which allows the recycling of adsorbent (Table 1). The chromate anions are recovered by adding stoichiometric amounts of $\mathrm{KOH}$ solution to the $\mathrm{Cr}(\mathrm{VI})$ solution to yield potassium chromate powder after solvent evaporation (Figure 15). This is in agreement with the proposed reaction pathway of $\mathrm{PW}_{10} \mathrm{Cr}_{2}$ (aq) species [22]. Most importantly, we are able to isolate this intermediate species.

The adsorption of hexavalent chromium anions by $\mathrm{Fe}_{3} \mathrm{O}_{4} @ \mathrm{SiO}_{2} @ \mathrm{LEuH} @ \mathrm{PW}_{10}$ is stable in the pH range of 4 12 (Figure 16(a)). It is noted that other mechanisms other than adsorption could have contributed to chromium removal from the studied water due to $\mathrm{pH}$ variations. The maximum time required for complete adsorption of $100 \mathrm{ppm}$ chromate anions by $0.2 \mathrm{~g}$ of the $\mathrm{Fe}_{3} \mathrm{O}_{4} @ \mathrm{SiO}_{2} @ \mathrm{LEuH} @ \mathrm{PW}_{10}$ nanocomposite is 42 minutes at $25^{\circ} \mathrm{C}$ (Figure 16(b)). This adsorption time might be acceptable for industrial wastewater treatment. Therefore, it can be concluded that the nanocomposite material is effective in treating wastewater and tap water in a relatively wide $\mathrm{pH}$ range.

To show the temperature effect on adsorption of $\mathrm{Cr}(\mathrm{VI})$ by the $\mathrm{Fe}_{3} \mathrm{O}_{4} @ \mathrm{SiO}_{2} @ \mathrm{LEuH} @ \mathrm{PW}_{10}$ nanocomposite, the experiments were investigated and the results are presented in Figure 17, in which curve $a$ is the desorption curve and curve $b$ is the adsorption curve. The optimized adsorption temperature of chromate anions is $25^{\circ} \mathrm{C}$. It is noted that the active sites ( $\mathrm{PW}_{10}$ anions) of $\mathrm{Fe}_{3} \mathrm{O}_{4} @ \mathrm{SiO}_{2} @ \mathrm{LEuH} @ \mathrm{PW}_{10} \mathrm{Cr}_{2}$ start to lose the adsorbed chromate anions at $T \geq 40^{\circ} \mathrm{C}$ as shown in Figure 17. The Gibbs free energies of the absorption system of the $\mathrm{Fe}_{3} \mathrm{O}_{4} @ \mathrm{SiO}_{2} @ \mathrm{LEuH} @ \mathrm{PW}_{10}$ and desorption system of $\mathrm{Fe}_{3} \mathrm{O}_{4} @ \mathrm{SiO}_{2} @ \mathrm{LEuH} @ \mathrm{PW}_{10} \mathrm{Cr}_{2}$ nanocomposites have been determined based on equations (5)-(9), where $R$ is the gas constant $\left(8.314 \mathrm{~J} \cdot \mathrm{k}^{-1} \cdot \mathrm{mol}^{-1}\right), T$ is the absolute temperature, $\Delta H$ is the enthalpy change, and $\Delta S$ is the entropy change. Equilibrium constant values, $K_{c}$, for the abovementioned two systems are evaluated at different $T$ according to equation (1), where $q_{e}$ is the equilibrium concentration of chromate concentration on the adsorbent and $C_{e}$ is the equilibrium concentration of chromate in solution:

$$
\begin{aligned}
K_{c} & =\frac{q_{e}}{C_{e}}, \\
\Delta G & =-\mathrm{RT} \ln K_{c}, \\
\ln \quad K_{c} & =\frac{\Delta H}{\mathrm{RT}}+\frac{\Delta S}{R}, \\
\Delta S & =\frac{\Delta H-\Delta G}{T}, \\
\frac{C}{Q} & =\frac{1}{q_{m} K_{L}}+\frac{1}{q_{m}} C, \\
\frac{t}{q_{t}} & =\frac{1}{k_{2} q_{e}^{2}}+\frac{1}{q_{e}} t, \\
\mathrm{PW}_{10}+\mathrm{CrO}_{4(\text { soln })}^{2-} & \stackrel{k_{2}}{\longrightarrow} \mathrm{PW}_{10} \mathrm{Cr}_{2 \text { (solid phase) }} .
\end{aligned}
$$



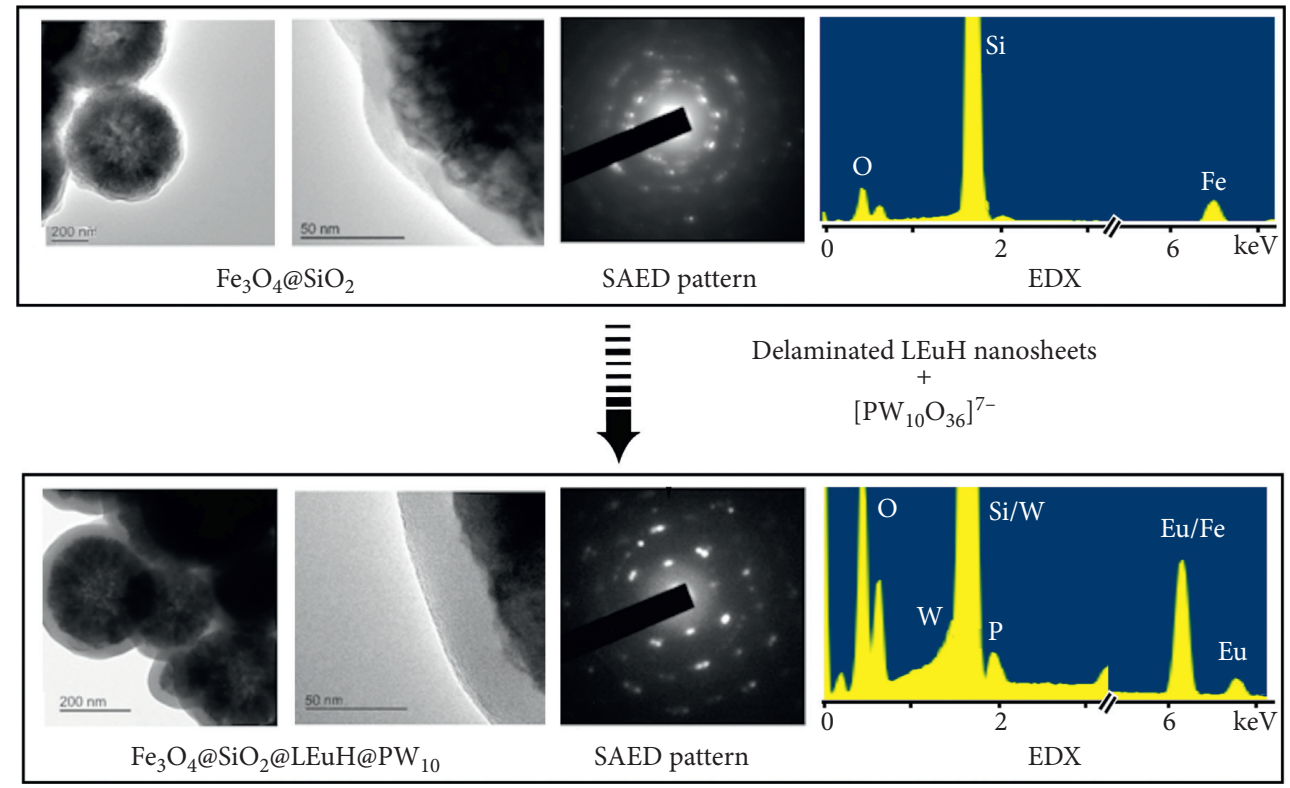

FIGURE 11: HRTEM, SAED patterns, and EDX images of the as-synthesized core-shell nanostructured $\mathrm{PW}_{10} \mathrm{O}_{36}{ }^{7-} \mathrm{material}_{(\mathrm{Si}}$ is from the silicon wafer).



(a)

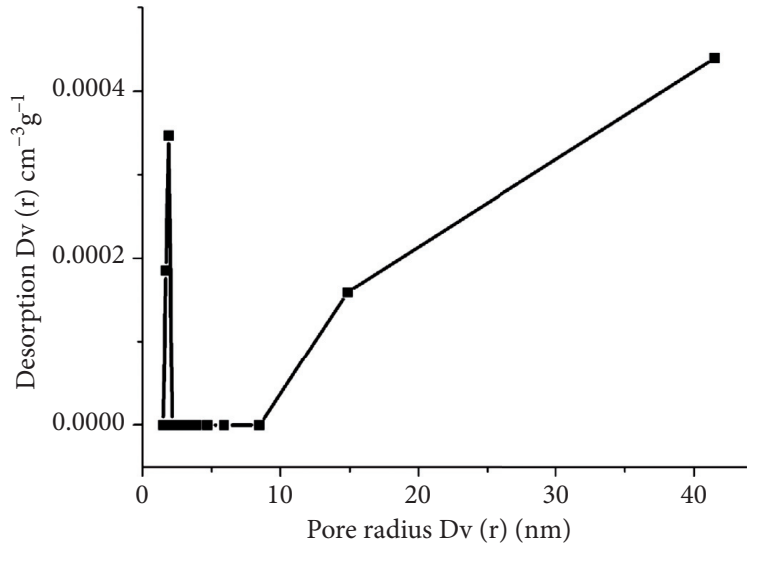

(b)

FIgURE 12: (a) $\mathrm{N}_{2}$ sorption isotherms and (b) pore size distribution of $\mathrm{Fe}_{3} \mathrm{O}_{4} @ \mathrm{SiO}_{2} @ \mathrm{LEuH} @ \mathrm{PW} \mathrm{H}_{10}$ nanospheres (type III isotherm): the abrupt rise near $P / P_{o}=1$ is due to the pores within the nanomaterial and not on the surface of the nanomaterial.

Plots of $\ln K_{c}$ versus $1 / T$ give straight lines with positive slope for temperature between $25^{\circ} \mathrm{C}$ and $40^{\circ} \mathrm{C}$ whereas negative slope at temperatures between $25^{\circ} \mathrm{C}$ and $10^{\circ} \mathrm{C}$ (Figure 17). $\Delta G$ for chromate adsorption is calculated from curve $b$ at $298 \mathrm{~K}^{-1}$ to be $-3.151 \times 10^{6} \mathrm{~J}$, indicating the reaction to be favorable. The values of $\Delta H$ and $\Delta S$ for the adsorption can be calculated to be $-2.83 \times 10^{5} \mathrm{~J} \cdot \mathrm{mol}^{-1}$ and $9.81 \times 10^{2} \mathrm{~J} \cdot \mathrm{K}^{-1}$, respectively.

The negative $\Delta H$ value suggests the exothermic character of the reaction between $\mathrm{Fe}_{3} \mathrm{O}_{4} @ \mathrm{SiO}_{2} @ \mathrm{LEuH} @$ $\mathrm{PW}_{10}$ nanocomposite material and the $\mathrm{Cr}(\mathrm{VI})$ anions in the adsorption process, whereas the positive $\Delta S$ value indicates the increase of the randomness. In contrast, for desorption of chromate anions, the values of $\Delta \mathrm{H}$ and $\Delta \mathrm{S}$ are $3.45 \times 10^{5} \mathrm{~J} \cdot \mathrm{mol}^{-1}$ and $-1.13 \times 10^{3} \mathrm{JK}^{-1}$, respectively (curve a). The positive $\Delta H$ value indicates the endothermic character of $\mathrm{Fe}_{3} \mathrm{O}_{4} @ \mathrm{SiO}_{2} @ \mathrm{LEuH} @ \mathrm{PW}_{10} \mathrm{Cr}_{2}$ losing the chromate anions. And the negative $\Delta S$ value suggests the decrease of the randomness.

The desorption could also result from the antiferromagnetism of chromium. Before $38^{\circ} \mathrm{C}$, chromium possesses antiferromagnetic properties. The $t=38^{\circ} \mathrm{C}$ is the Neel 


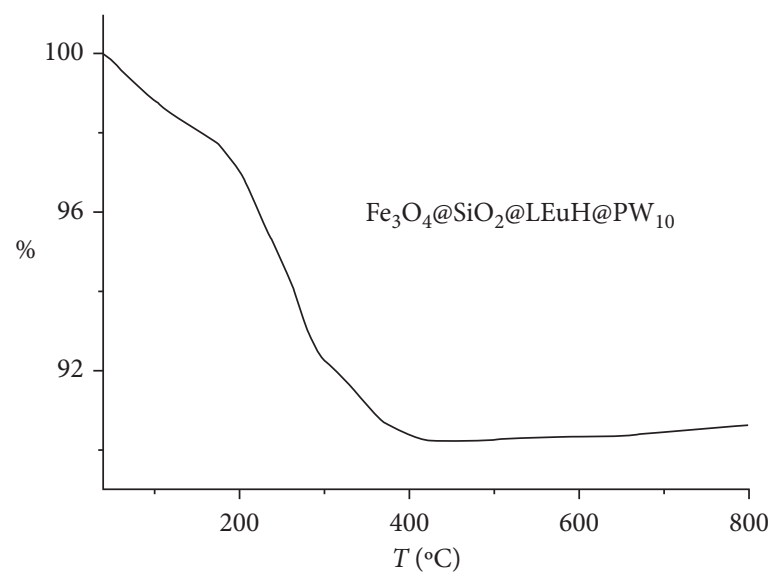

Figure 13: Thermogravimetric analysis curves for $\mathrm{Fe}_{3} \mathrm{O}_{4} @ \mathrm{SiO}_{2} @ \mathrm{LEuH} @ \mathrm{PW}_{10}$.
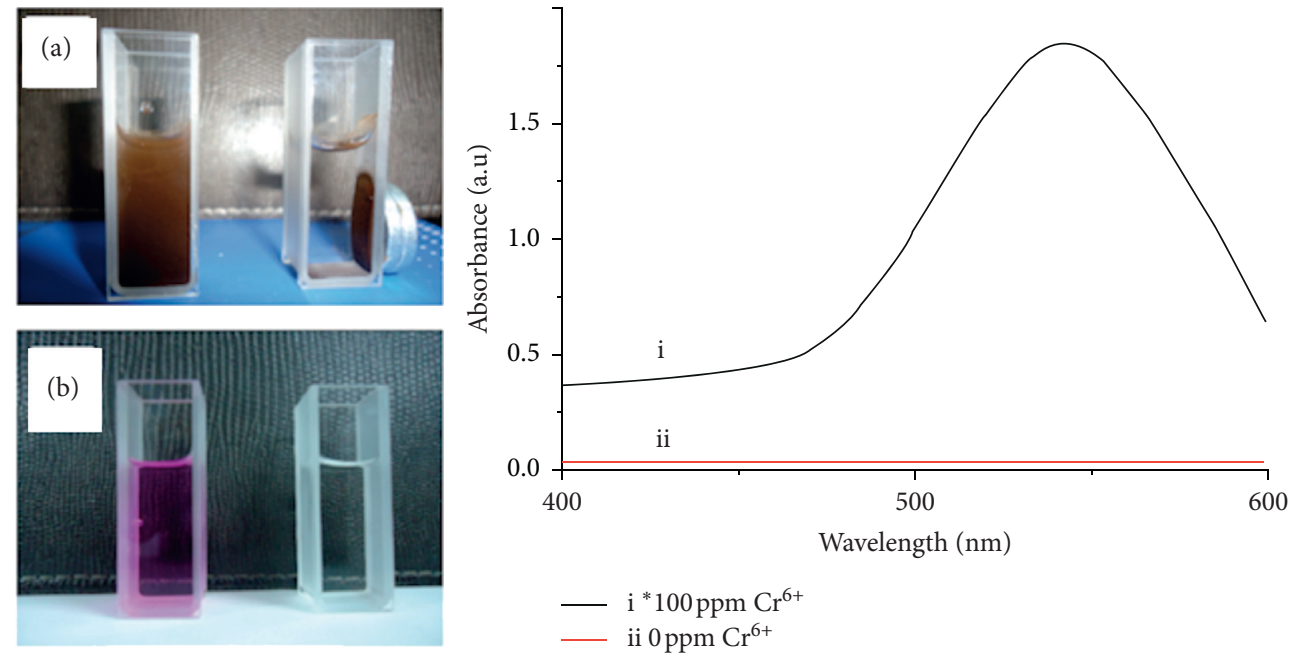

(c)

FIGURE 14: (a) Magnetic separation of a sample after reaction; (b) sample prepared for UV analysis using 1,5-diphenylcarbazide reagent. (c) A sample reduced from an initial concentration of 100 ppm to 0 ppm $\mathrm{Cr}(\mathrm{VI})$ with $\mathrm{Fe}_{3} \mathrm{O}_{4} @ \mathrm{SiO}_{2} @ \mathrm{LEuH} @ \mathrm{PW}{ }_{10}$ after 1 hour reaction time at $24^{\circ} \mathrm{C}$ and $\mathrm{pH} 6 ;^{*}$ dilution factor $=20$.

TABLE 1: Test results of $0.4 \mathrm{~g} \mathrm{Fe}_{3} \mathrm{O}_{4} @ \mathrm{SiO}_{2} @ \mathrm{LEuH} @ \mathrm{PW}_{10}$ adsorbent with different chromate concentrations in both tap water and wastewater at $25^{\circ} \mathrm{C}$ for 1 hour at $\mathrm{pH}=6$ for tap water and $\mathrm{pH}=4.4$ for wastewater.

\begin{tabular}{|c|c|c|c|c|}
\hline Test material & Volume (ml) & Initial $\mathrm{CrO}_{4}{ }^{2-}(\mathrm{ppm})$ & Final $\mathrm{CrO}_{4}{ }^{2-}(\mathrm{ppm})$ & Adsorbent reuse* \\
\hline \multirow{4}{*}{ Tap water } & 100 & 2 & ND & ND \\
\hline & 200 & 2 & ND & ND \\
\hline & 300 & 2 & ND & ND \\
\hline & 500 & 2 & ND & ND \\
\hline \multirow{4}{*}{ Wastewater } & 100 & 2 & ND & ND \\
\hline & 200 & 2 & ND & ND \\
\hline & 300 & 2 & ND & ND \\
\hline & 500 & 2 & ND & ND \\
\hline \multirow{4}{*}{ Tap water ${ }^{\dagger}$} & 100 & 100 & ND & ND \\
\hline & 200 & 100 & ND & ND \\
\hline & 300 & 100 & ND & ND \\
\hline & 500 & 100 & ND & ND \\
\hline \multirow{4}{*}{ Wastewater ${ }^{\dagger}$} & 100 & 100 & ND & ND \\
\hline & 200 & 100 & ND & ND \\
\hline & 300 & 100 & ND & ND \\
\hline & 500 & 100 & ND & ND \\
\hline
\end{tabular}

Note. Below detection limit (ND) was $0.007 \mathrm{ppm} .{ }^{*}$ Adsorbent reused ten times giving similar results; ${ }^{\dagger} 4.0 \mathrm{~g}$ of adsorbent used. 


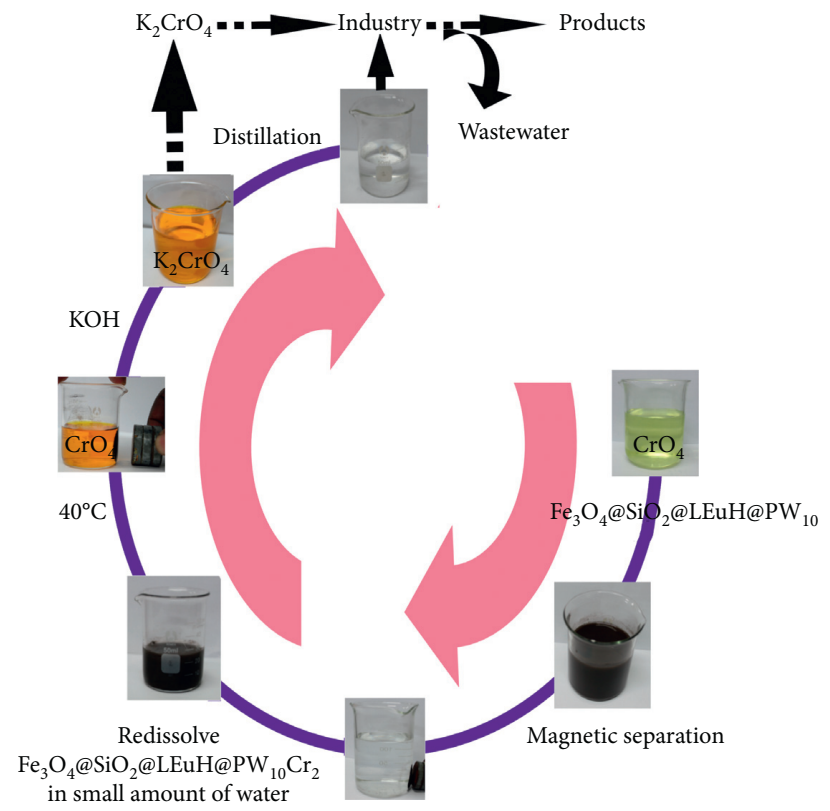

FIGURE 15: Schematic presentation of hexavalent chromium removal from wastewater and reusability mechanisms.



(a)

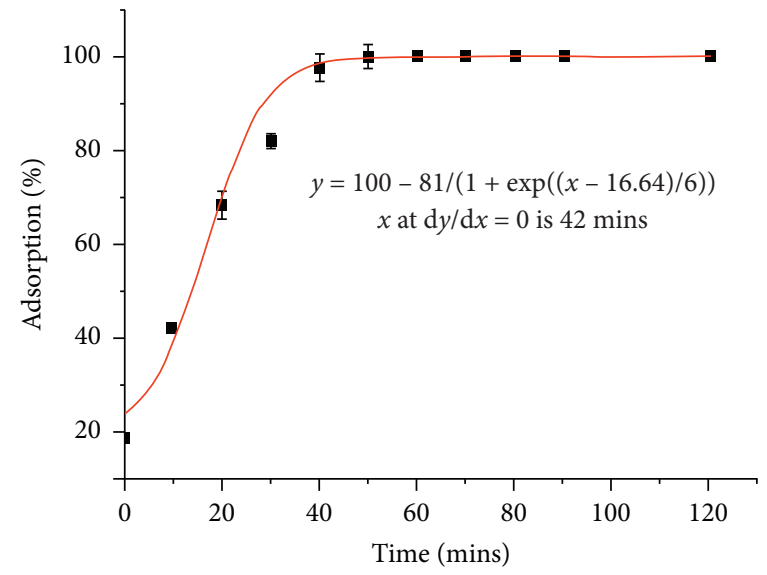

(b)

Figure 16: (a) Effect of $\mathrm{pH}$ on adsorption of $\mathrm{Cr}(\mathrm{VI})(100 \mathrm{ppm}$ in $50 \mathrm{ml})$ by $0.2 \mathrm{~g}$ of $\mathrm{Fe}_{3} \mathrm{O}_{4} @ \mathrm{SiO}_{2} @ \mathrm{LEuH}_{\mathrm{P}} \mathrm{PW}$ 10; reaction time = 1 hour at

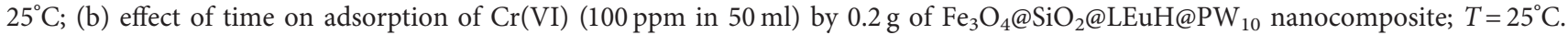

temperature for chromium [33]. That is why it easily desorbed from adsorbent's surface under temperature higher than $40^{\circ} \mathrm{C}$.

As shown in Figure 18, the adsorption profiles fit perfectly with the Langmuir adsorption model. The maximum uptake capacity of the $\mathrm{Fe}_{3} \mathrm{O}_{4} @ \mathrm{SiO}_{2} @ \mathrm{LEuH} @ \mathrm{PW}_{10}$ nanocomposite for chromate anions, $q_{m}$, can be determined from the reciprocal of the slopes of the straight lines in Figure 18(b). This corresponds well to the determined $q_{m}$ from the Langmuir isotherm curve in Figure 18(a). The $\mathrm{ppm} / \mathrm{g}$ value is converted to $\mathrm{mmol} / \mathrm{g}$ by dividing it with molar mass of chromium to give $23 \mathrm{mmol} / \mathrm{g}$. It is, therefore, assumed that the adsorption sites are equivalent and have the same binding energy and can only form monolayer. The BET isotherm (Figure 12) provides further evidence for the above assumptions with a type III isotherm graph, indicating the absence of pores in the adsorption process and the evidence for the monolayer adsorption-desorption behavior. The BET isotherm also rules out the possibility of physisorption mechanisms. As a result, chemisorption dominates the adsorption process.

However, it is important to point out that the vertical rise at $P / P_{0}$ region $=1$ (Figure 12 ), indicating the presence of macropores, is due to the spaces found in between the nanoparticles and not on the surface of the nanoparticles. This is particularly due to the size of the macropores, 


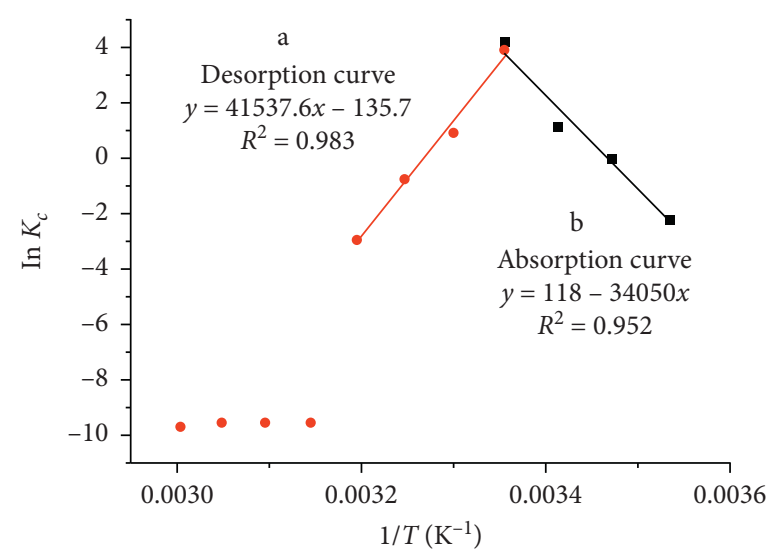

Figure 17: Effect of temperature on adsorption and desorption of $\mathrm{Cr}(\mathrm{VI})$ (100 ppm in $50 \mathrm{ml})$ by $0.2 \mathrm{~g} \mathrm{Fe}_{3} \mathrm{O}_{4} @ \mathrm{SiO}_{2} @ \mathrm{LEuH}_{\mathrm{H}} @ \mathrm{PW}$ 10.

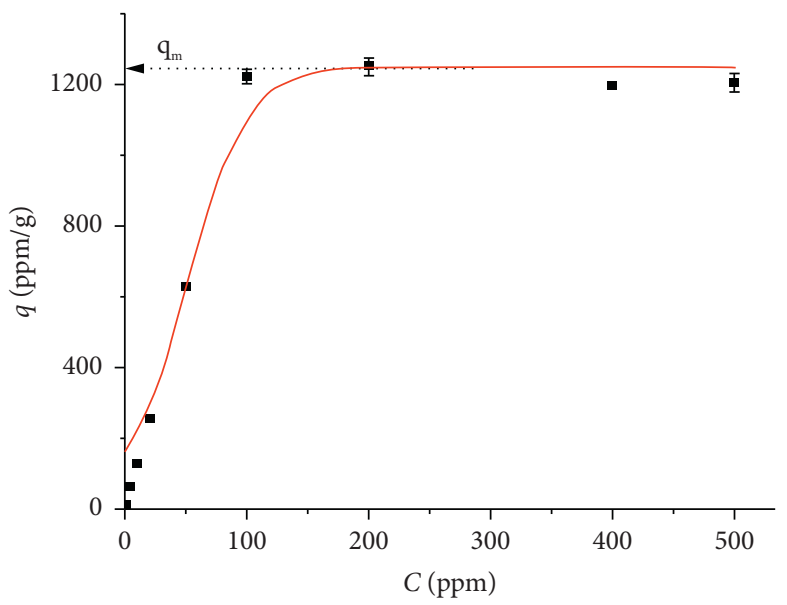

(a)

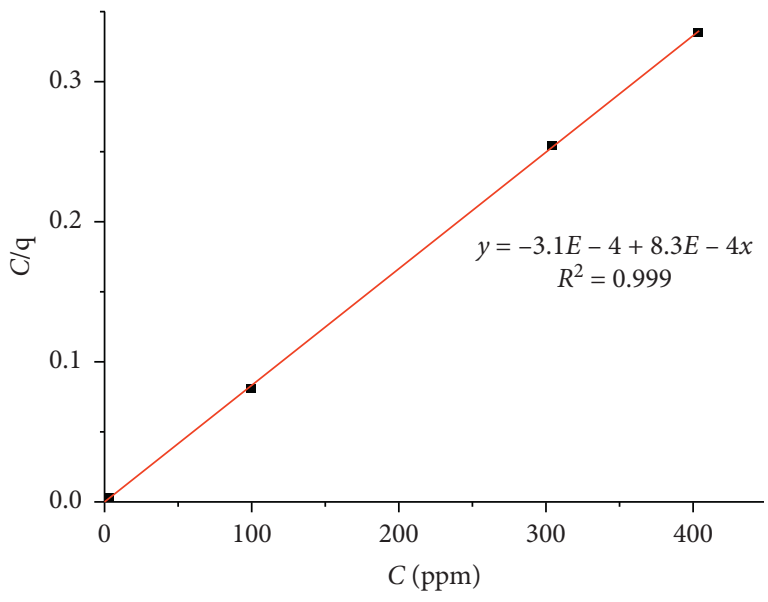

(b)

Figure 18: (a) Optimal adsorbed amount $\left(q_{m}\right)$ and $(b)$ the Langmuir adsorption isotherm of $\mathrm{Cr}(\mathrm{VI})$ by $\mathrm{Fe}_{3} \mathrm{O}_{4} @ \mathrm{SiO}_{2} @ \mathrm{LEuH} @ \mathrm{PW}_{10}$ nanocomposite at $25^{\circ} \mathrm{C}$ and $\mathrm{pH}=6$.

diameter $60.7 \mathrm{~nm}$ determined by BET experiments, which would otherwise be visible in SEM and TEM images (Figures 10 and 11).

The Langmuir isotherm is valid for monolayer sorption onto a surface with a finite number of identical sites and uniform adsorption energies [34,35]. The model postulates a homogenous surface for the adsorbent. Accordingly, the fitting of our results to this model supports the proposed structure of the $\mathrm{Fe}_{3} \mathrm{O}_{4} @ \mathrm{SiO}_{2} @ \mathrm{LEuH} @ \mathrm{PW}_{10}$ nanocomposite (Figure 2).

To further verify the chemisorption process, pseudo-second-order rate expression, commonly used for analyzing chemisorption kinetics [36], is applied at low initial concentrations of $\mathrm{Cr}(\mathrm{VI})$ anions. The pseudo-second-order model constant, $k_{2}$, can be determined experimentally by plotting $t / q_{t}$ against $t$ from equation (10) to obtain the graph in Figure 19. The activation energy $E_{a}$ can be determined from plots of $\ln k_{2}$ versus $1 / T$ to yield a straight line, with slope $-E a / R$ (Figure 19) according to the Arrhenius equation [37]. In equation (10),

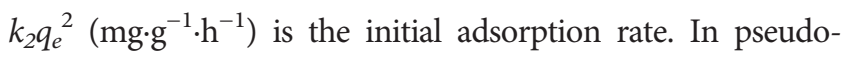
second-order rate expression, it is assumed that two chromate anions $\left(\mathrm{CrO}_{4}{ }^{2-}\right)$ can be adsorbed onto one sorption site $\left(\mathrm{PW}_{10}\right)$ on the surface of the $\mathrm{Fe}_{3} \mathrm{O}_{4} @ \mathrm{SiO}_{2} @ \mathrm{LEuH} @ \mathrm{PW}_{10}$ nanocomposite (equation (11)). The Van't Hoff plot shows the reaction requires an activation energy of $44.22 \mathrm{~kJ} / \mathrm{mol}$, which falls in the range of $40 \sim 800 \mathrm{~kJ} / \mathrm{mol}$ [37]. This result again supports the chemisorption process. Other models can be applied to test the chemisorption behavior including Elovich kinetic model $[38,39]$.

3.3. Catalytic Activity of $\mathrm{Fe}_{3} \mathrm{O}_{4} @ \mathrm{SiO}_{2} @ L E u H @ P W_{10}$. By using $\mathrm{NH}_{4} \mathrm{Br}$ and $\mathrm{H}_{2} \mathrm{O}_{2}$ as feedstock, phenol red was successfully catalysed to bromophenol blue using $\mathrm{Fe}_{3} \mathrm{O}_{4} @$ $\mathrm{SiO}_{2} @ \mathrm{LEuH} @ \mathrm{PW}_{10}$ nanocomposite material as a catalyst (Table 2). The bromination reaction catalysed by $\mathrm{Fe}_{3} \mathrm{O}_{4} @$ $\mathrm{SiO}_{2} @ \mathrm{LEuH} @ \mathrm{PW}_{10}$ nanocomposite material was monitored at time intervals of 30 seconds (Figure 20). The reaction was 


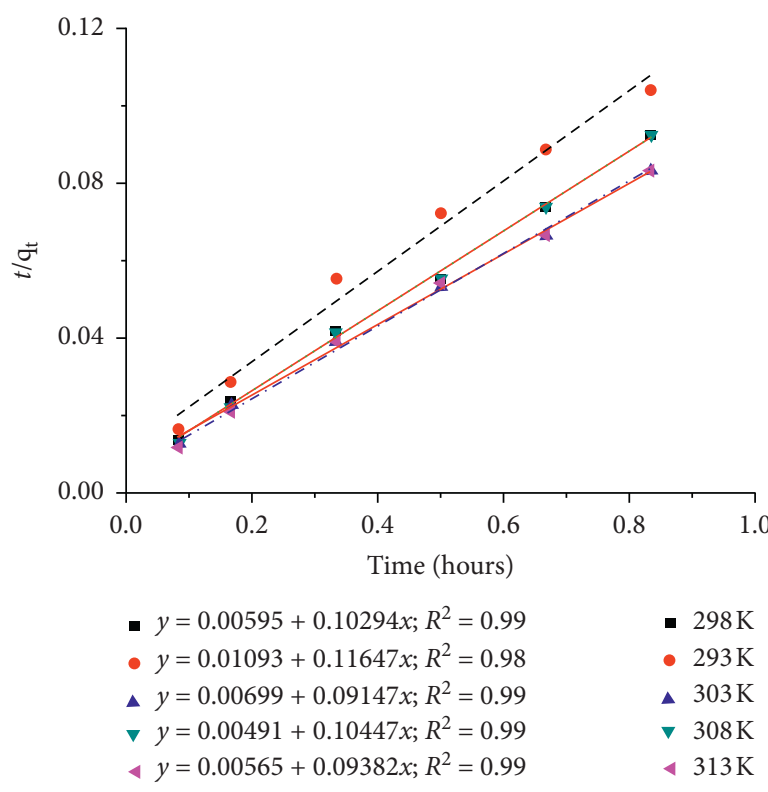

(a)

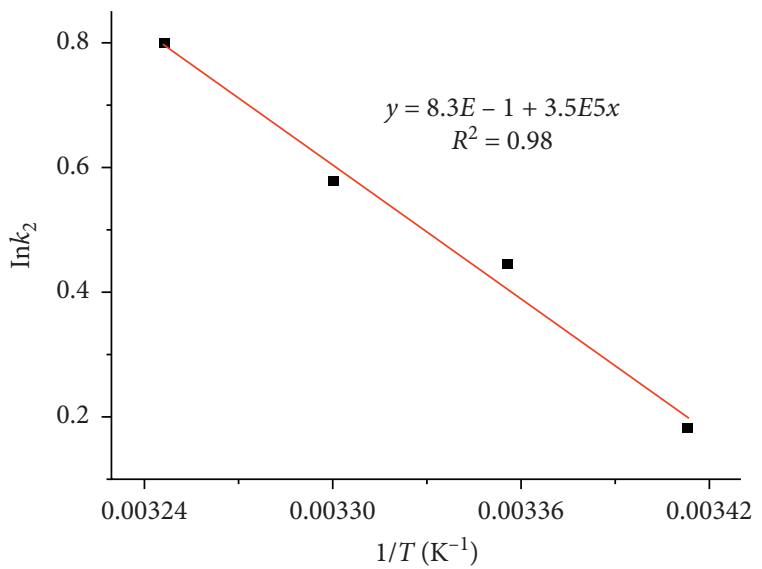

(b)

Figure 19: (a) Pseudo-second-order kinetics of $\mathrm{Cr}(\mathrm{VI})$ sorption onto $0.02 \mathrm{~g}$ of $\mathrm{Fe}_{3} \mathrm{O}_{4} @ \mathrm{SiO}_{2} @ \mathrm{LEuH} @ \mathrm{PW}$ 10 at various temperatures: low concentration of $10 \mathrm{ppm} \mathrm{Cr}(\mathrm{VI})$ solution used. (b) Van't Hoff plot for determination of activation energy in the adsorption mechanisms of $\mathrm{Fe}_{3} \mathrm{O}_{4} @ \mathrm{SiO}_{2} @ \mathrm{LEuH} @ \mathrm{PW}_{10}$ with $\mathrm{CrO}_{4}{ }^{2-}$.

TABle 2: Catalytic bromination activities of $\mathrm{LEuH}-\mathrm{Cl}, \mathrm{Fe}_{3} \mathrm{O}_{4}, \mathrm{Fe}_{3} \mathrm{O}_{4} @ \mathrm{SiO}_{2}$, and $\mathrm{Fe}_{3} \mathrm{O}_{4} @ \mathrm{SiO}_{2} @ \mathrm{PW}_{10}$ catalysts.

\begin{tabular}{|c|c|c|c|c|c|}
\hline Entry & Catalyst & BET surface area $\left(\mathrm{m}^{3} / \mathrm{g}\right)$ & Yield (\%) & Time (h) & Rate $\left(\mathrm{mmol} \cdot \mathrm{g}^{-1} \mathrm{~s}^{-1}\right)$ \\
\hline 1 & LEuH-Cl & 57.30 & 22 & 2 & $1.22 * 10^{-7}$ \\
\hline 2 & $\mathrm{Fe}_{3} \mathrm{O}_{4}$ & 7.32 & 23 & 2 & $1.28^{*} 10^{-7}$ \\
\hline 3 & $\mathrm{Fe}_{3} \mathrm{O}_{4} @ \mathrm{SiO}_{2}$ & 13.57 & 21 & 2 & $1.17^{*} 10^{-7}$ \\
\hline 4 & $\mathrm{Fe}_{3} \mathrm{O}_{4} @ \mathrm{SiO}_{2} @ \mathrm{LEuH} @ \mathrm{PW}_{10}$ & 16.62 & 99 & 0.1 & $5.5^{*} 10^{-3}$ \\
\hline
\end{tabular}

Reaction conditions are as follows: $10 \mathrm{ml}$ of $1.0 \mathrm{mM}$ phenol red in water $+10 \mathrm{ml}$ of $10.0 \mathrm{mM} \mathrm{NH}_{4} \mathrm{Br}$ in water $+0.5 \mathrm{~g}$ of catalyst $+2.5 \mathrm{mM} \cdot \mathrm{H}_{2} \mathrm{O}_{2}$, in a roundbottomed flask. Time $=10$ minutes, $T=298 \mathrm{~K}$, and $P=1 \mathrm{~atm}$. Rate of conversion $=$ mole $\mathrm{Br}^{-}$oxidized per total weight of catalyst (g) per second. Symbol “*” denotes a multiplication sign.

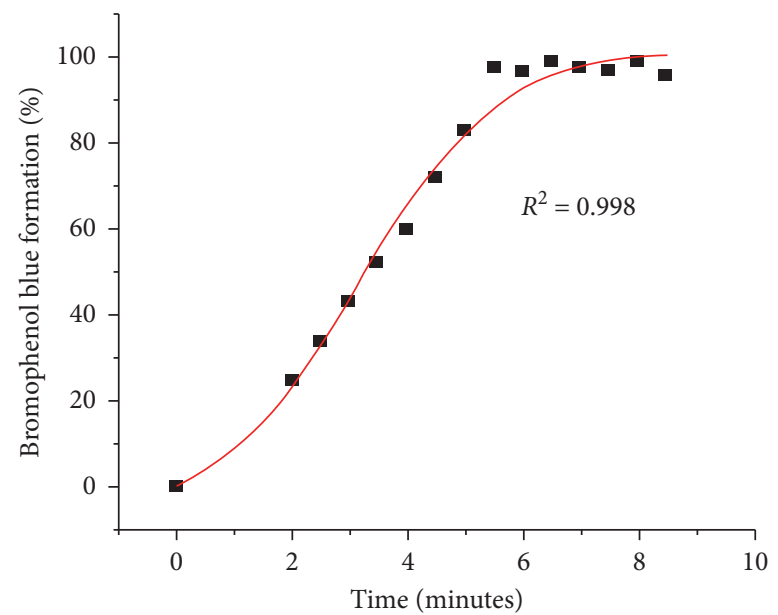

FIgURE 20: Bromination of phenol red to bromophenol blue using $\mathrm{Fe}_{3} \mathrm{O}_{4} @ \mathrm{SiO}_{2} @ \mathrm{LEuH}_{\mathrm{P}} \mathrm{PW}$ as a POM nanocomposite catalyst. The reaction was monitored at time intervals of 30 seconds $(1=0 \mathrm{~s}, 2=30 \mathrm{~s}, \ldots, 12=330 \mathrm{~s})$. Reaction conditions are as follows: $10 \mathrm{ml}$ of $1.0 \mathrm{mM}$ phenol red in water $+10 \mathrm{ml}$ of $10.0 \mathrm{mM} \mathrm{NH} \mathrm{mHr}_{4}$ in water $+0.5 \mathrm{~g}$ of catalyst $+2.5 \mathrm{mM} \cdot \mathrm{H}_{2} \mathrm{O}_{2}$, in a round-bottomed flask. $T=298 \mathrm{~K}$ and $P=1 \mathrm{~atm}$. 




(a)

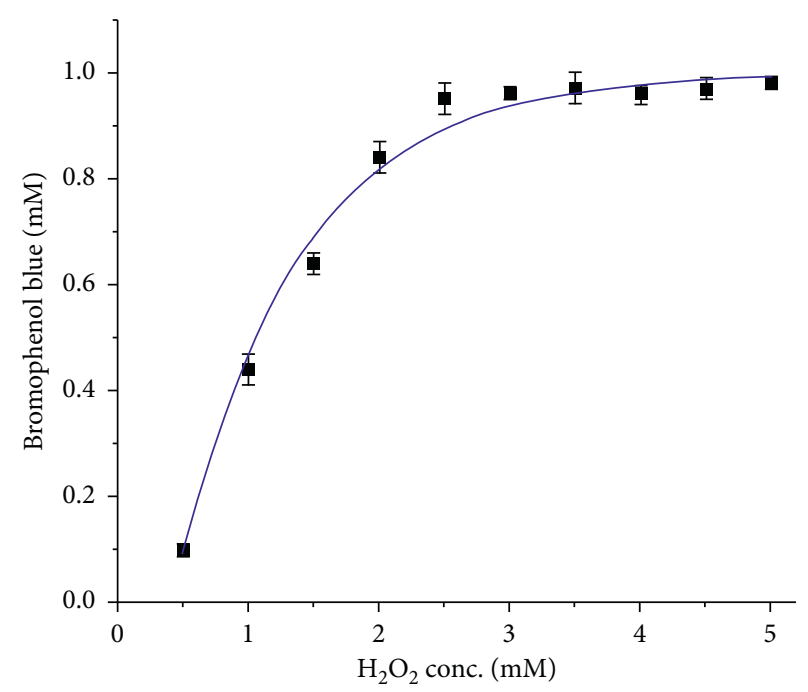

(b)

FIGURE 21: Effect of (a) amount of catalyst $\left(\mathrm{Fe}_{3} \mathrm{O}_{4} @ \mathrm{SiO}_{2} @ \mathrm{LEuH} @ \mathrm{PW}_{10}\right)$ and (b) amount of $\mathrm{H}_{2} \mathrm{O}_{2}$ used in bromination of phenol red to bromophenol blue. Reaction conditions are as follows $10 \mathrm{ml}$ of $1.0 \mathrm{mM}$ phenol red in water $+10 \mathrm{ml}$ of $10.0 \mathrm{mM} \mathrm{NH}_{4} \mathrm{Br}$ in water $+2.5 \mathrm{mM}$ $\mathrm{H}_{2} \mathrm{O}_{2}$ in reaction $\mathrm{a}+0.5 \mathrm{~g}$ of catalyst in reaction $\mathrm{b}$, in a round-bottomed flask. Time $=10$ minutes, $T=298 \mathrm{~K}$, and $P=1 \mathrm{~atm}$.

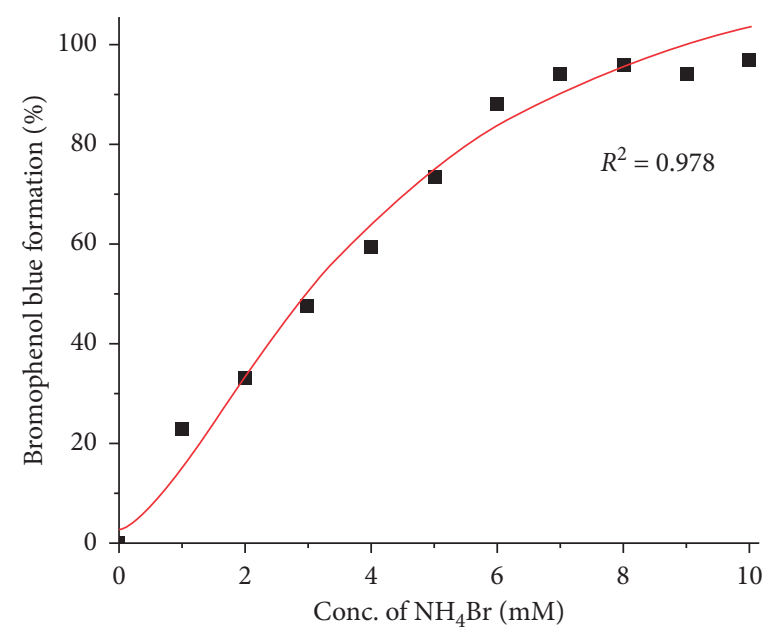

Figure 22: Effect of different concentrations of $\mathrm{NH}_{4} \mathrm{Br}(1=0,2=2, \ldots, 10=10 \mathrm{mM})$ on the rate of formation of bromophenol blue after 10 minutes. Reaction conditions are as follows: $10 \mathrm{ml}$ of $1.0 \mathrm{mM}$ phenol red in water $+10 \mathrm{ml}$ of $10.0 \mathrm{mM} \mathrm{NH}_{4} \mathrm{Br}$ in water $+0.5 \mathrm{~g}$ of catalyst $+2.5 \mathrm{mM} \mathrm{H}_{2} \mathrm{O}_{2}$, in a round-bottomed flask. $T=298 \mathrm{~K}$ and $P=1 \mathrm{~atm}$.

complete in 10 minutes with a $99 \%$ conversion of phenol red to bromophenol blue (Figure 20). Contrast experiments suggest that $\mathrm{LEuH}-\mathrm{Cl}, \mathrm{Fe}_{3} \mathrm{O}_{4}$, and $\mathrm{Fe}_{3} \mathrm{O}_{4} @ \mathrm{SiO}_{2}$ exhibit 22\%, $23 \%$, and $21 \%$ yield in 2 hours, respectively (Table 2). It is noted that there was no formation of bromophenol blue in the first 1.5 minutes (Figure 20), despite a reduction in the concentration of the starting material, phenol red. However, after 2 minutes, the level of bromophenol blue in the reaction mixture raises steadily and reaches its maximum after 10 minutes (Figure 20).

The reduction in the concentration of phenol red in the first 1.5 minutes is probably due to the formation of an intermediate compound that does not absorb UV light in the tested region. Optimal conditions of the bromination reaction were experimentally determined (Figures 21 and 22). For instance, the maximum catalyst amount was determined as $0.5 \mathrm{~g}$ for the $\mathrm{Fe}_{3} \mathrm{O}_{4} @ \mathrm{SiO}_{2} @ \mathrm{LEuH} @ \mathrm{PW}_{10}$ nanocomposite material (Figure 21(a)), while the maximum $\mathrm{H}_{2} \mathrm{O}_{2}$ concentration was $2.5 \mathrm{mM}$ (Figure $21(\mathrm{~b})$ ). $\mathrm{NH}_{4} \mathrm{Br}$ is the ratedetermining reagent in the bromination of phenol red to bromophenol blue (Figure 22).

Under similar experimental conditions, bromination of phenol red to bromophenol blue using LDH/POM intercalated catalyst took 32 minutes to complete [40], while the 


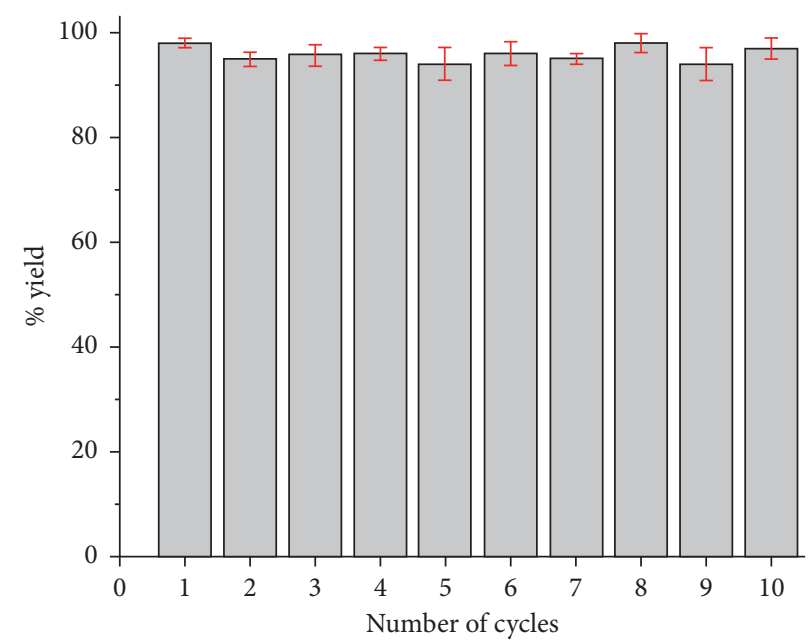

FIGURE 23: Reuse of $\mathrm{Fe}_{3} \mathrm{O}_{4} @ \mathrm{SiO}_{2} @ \mathrm{LEuH} @ \mathrm{PW}_{10}$ catalyst for the conversion of phenol to bromophenol blue. The experimental conditions included $10 \mathrm{ml}$ of $1.0 \mathrm{mM}$ phenol red $+10 \mathrm{ml}$ of $10.0 \mathrm{mM} \mathrm{NH}_{4} \mathrm{Br}+0.5 \mathrm{~g}$ of catalyst $+2.5 \mathrm{mM} \mathrm{H}_{2} \mathrm{O}_{2}$, in a round-bottomed flask. Time $=10$ minutes, $T=298 \mathrm{~K}$, and $P=1 \mathrm{~atm}$.

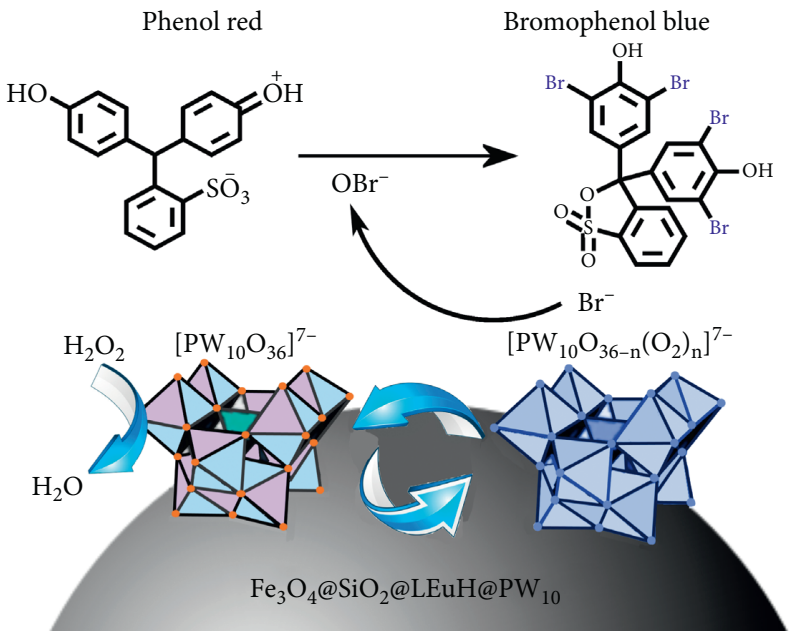

FIGURE 24: The proposed mechanism of reaction for the bromination of phenol red to bromophenol blue using $\mathrm{Fe}_{3} \mathrm{O}_{4} @ \mathrm{SiO}_{2} @ \mathrm{LEuH}_{\mathrm{H}} @ \mathrm{PW}_{10}$ as a catalyst.

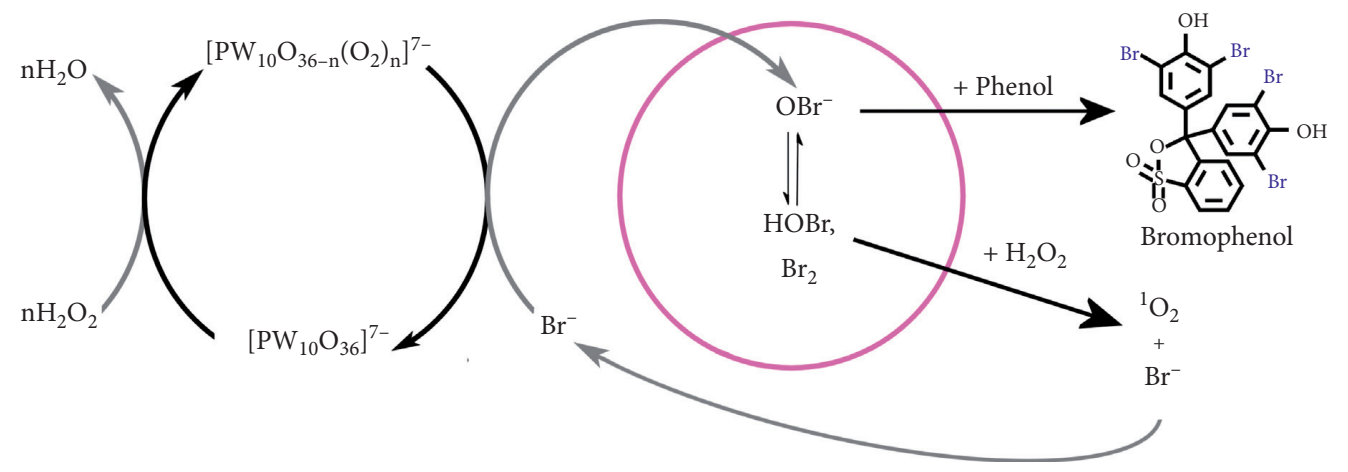

FIGURE 25: The proposed full reaction mechanism of the limiting reagent $\mathrm{NH}_{4} \mathrm{Br}$ producing molecular oxygen. 
new $\mathrm{Fe}_{3} \mathrm{O}_{4} @ \mathrm{SiO}_{2} @ \mathrm{LEuH} @ \mathrm{PW}_{10}$ nanocomposite material takes less than 10 minutes to complete a similar reaction (Figure 20). Moreover, in addition to ease of catalyst separation from the products using an external magnet, the nanocomposite can be reusable for at least 10 catalytic circles with no obvious loss of activity observed (Figure 23).

The mechanism of the reaction is proposed in Figure 24. In the presence of $\mathrm{H}_{2} \mathrm{O}_{2}$, the active $\mathrm{W}$-peroxo species can be formed on the surface of the spherical $\mathrm{Fe}_{3} \mathrm{O}_{4} @ \mathrm{SiO}_{2} @ \mathrm{LEuH} @$ $\mathrm{PW}_{10}$ nanocomposite. The $\mathrm{W}$-peroxo species are readily reduced by the bromide ions from $\mathrm{NH}_{4} \mathrm{Br}$ (aq), in which the activated oxygens from peroxotungstate can be transferred to $\mathrm{Br}^{-}$to get a 2-electron oxidation in solution, which results into $\mathrm{OBr}^{-}$formation. These $\mathrm{OBr}^{-}$radicals are then involved in an electrophilic reaction with phenol red to get the bromophenol blue. These processes can be summarized in equations (12)-(14). Note that $n$ can be different according to the number of $\mathrm{W}=\mathrm{O}$ units exposed to $\mathrm{H}_{2} \mathrm{O}_{2}$. There are other side reactions in the system as demonstrated in Figure 25:

$$
n \mathrm{H}_{2} \mathrm{O}_{2}+\left[\mathrm{PW}_{10} \mathrm{O}_{36}\right]^{7-} \longrightarrow\left[\mathrm{PW}_{10} \mathrm{O}_{36-n}\left(\mathrm{O}_{2}\right)_{n}\right]^{7-}+n \mathrm{H}_{2} \mathrm{O}
$$

$$
\left[\mathrm{PW}_{10} \mathrm{O}_{36-n}\left(\mathrm{O}_{2}\right)_{n}\right]^{7-}+n \mathrm{Br}^{-} \longrightarrow\left[\mathrm{PW}_{10} \mathrm{O}_{36}\right]^{7-}+n \mathrm{OBr}^{-}
$$

$$
\mathrm{C}_{19} \mathrm{H}_{14} \mathrm{O}_{5} \mathrm{~S}+4 \mathrm{OBr}^{-} \longrightarrow \mathrm{C}_{19} \mathrm{H}_{10} \mathrm{Br}_{4} \mathrm{O}_{5} \mathrm{~S}+2 \mathrm{H}_{2} \mathrm{O}_{2}
$$

In summary, we present a new approach of effectively heterogenizing $\mathrm{PW}_{10}$ anions on a magnetically active nanospherical support material. The catalytic versatility of the as-synthesized $\mathrm{Fe}_{3} \mathrm{O}_{4} @ \mathrm{SiO}_{2} @ L E u H @ \mathrm{PW}_{10}$ nanocomposite material has been demonstrated by the conversion of phenol red to bromophenol blue. In this reaction, $\mathrm{Fe}_{3} \mathrm{O}_{4} @ \mathrm{SiO}_{2} @ \mathrm{LEuH} @ \mathrm{PW}_{10}$ takes less than 10 minutes to complete the conversion under the experimental conditions as compared to 32 minutes for LDHs. Moreover, the nanocomposite of $\mathrm{Fe}_{3} \mathrm{O}_{4} @ \mathrm{SiO}_{2} @ \mathrm{LEuH} @ \mathrm{PW} \mathrm{H}_{10}$ can be reused (minimum 10 times tested) with almost similar results obtained. In addition, it can be easily be separated using an external magnet.

\section{Conclusion}

The immobilization of $\mathrm{PW}_{10}$ onto $\mathrm{Fe}_{3} \mathrm{O}_{4} @ \mathrm{SiO}_{2}$ using $\mathrm{LEuH}$ nanosheets results in the formation of a new

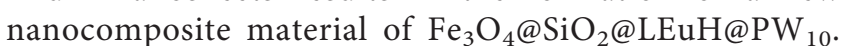
This nanocomposite material has been demonstrated to be able to chemically adsorb chromate anions from aqueous media. The adsorption reaction yields a $\mathrm{Cr}(\mathrm{VI})$ absorbed nanocomposite material $\left(\mathrm{Fe}_{3} \mathrm{O}_{4} @ \mathrm{SiO}_{2} @\right.$ LEuH@PW ${ }_{10} \mathrm{Cr}_{2}$ ), which loses the $\mathrm{Cr}(\mathrm{VI})$ anions at $\geq 40 \mathrm{C}$, resulting in the restoration of the original $\mathrm{Fe}_{3} \mathrm{O}_{4} @ \mathrm{SiO}_{2} @ \mathrm{LEuH} @ \mathrm{PW}_{10}$. The adsorption-desorption process can be repeated at least ten times without obvious loss of activity. Scale-up experimental results indicate that the magnetically active $\mathrm{Fe}_{3} \mathrm{O}_{4} @ \mathrm{SiO}_{2} @ \mathrm{LEuH}_{\mathrm{H}} @ \mathrm{PW}_{10}$ nanocomposite can be effective too. The chromate adsorption capacity of the synthesized $\mathrm{Fe}_{3} \mathrm{O}_{4} @ \mathrm{SiO}_{2} @$ LEuH@PW 10 nanocomposite is $23 \mathrm{mmol} / \mathrm{g}$ from aqueous solutions at $25^{\circ} \mathrm{C}$ for 42 minutes in the $\mathrm{pH}$ range of $4 \sim 12$ with an activation energy of $44.22 \mathrm{~kJ} / \mathrm{mol}$. The adsorption isotherms fit very well with the Langmuir model.

\section{Data Availability}

All the necessary information required for replication of this work and/or conducting secondary analysis are included within the article.

\section{Conflicts of Interest}

The authors declare that they have no conflicts of interest.

\section{Acknowledgments}

Financial support from National Research Fund of Kenya $(2016 / 17)$, the RSC Allan Ure Bursary Fund of 2017, and Jaramogi Oginga Odinga University of Science and Technology is acknowledged.

\section{References}

[1] J. A. Jacobs and S. M. Testa, "Overview of chromium (VI) in the environment: background and history," in Chromium (VI) Handbook, CRC Press, New York City, NY, USA, 2005.

[2] A. H. Stern, "A quantitative assessment of the carcinogenicity of hexavalent chromium by the oral route and its relevance to human exposure," Environmental Research, vol. 110, no. 8, pp. 798-807, 2010.

[3] S. Tahir and R. Naseem, "Removal of Cr (III) from tannery wastewater by adsorption onto bentonite clay," Separation and Purification Technology, vol. 53, no. 3, pp. 312-321, 2007.

[4] N. Fahim, B. Barsoum, A. Eid, and M. Khalil, "Removal of chromium (III) from tannery wastewater using activated carbon from sugar industrial waste," Journal of Hazardous Materials, vol. 136, no. 2, pp. 303-309, 2006.

[5] M. Jobbágy and A. E. Regazzoni, "Complexation at the edges of hydrotalcite: the cases of arsenate and chromate," Journal of Colloid and Interface Science, vol. 393, pp. 314-318, 2013.

[6] M. L. Peterson, G. E. Brown, and G. A. Parks, "Direct XAFS evidence for heterogeneous redox reaction at the aqueous chromium/magnetite interface," Colloids and Surfaces A: Physicochemical and Engineering Aspects, vol. 107, pp. 77-88, 1996.

[7] F. Y. Saleh, G. E. Mbamalu, Q. H. Jaradat, and C. E. Brungardt, "Ion chromatography-photodiode array UV-visible detection of $\mathrm{Cr}$ (III) hydrolytic polymerization products in pure and natural waters," Analytical Chemistry, vol. 68, no. 5, pp. 740-745, 1996.

[8] United States Environmental Protection Agency, Chromium in Drinking Water, United States Environmental Protection Agency, Washington, DC, USA, 2012, http://water.epa.gov/ drink/info/chromium/index.cfm 2013-05-16.

[9] United States Environmental Protection Agency, IRIS Toxicological Review of Hexavalent Chromium (2010 External Review Draft), United States Environmental Protection Agency, Washington, DC, USA, 2010, http://cfpub.epa.gov/ ncea/iris_drafts/recordisplay.cfm?deid=221433 2013-04-06. 
[10] M. Ajmal, A. A. Nomani, and A. Ahmad, "Acute toxicity of chrome electroplating wastes to microorganisms: adsorption of chromate and chromium (VI) on a mixture of clay and sand," Water, Air, and Soil Pollution, vol. 23, no. 2, pp. 119-127, 1984.

[11] R. M. Sedman, J. Beaumont, T. A. Mcdonald, S. Reynolds, G. Krowech, and R. Howd, "Review of the evidence regarding the carcinogenicity of hexavalent chromium in drinking water," Journal of Environmental Science and Health, Part C, vol. 24, no. 1, pp. 155-182, 2006.

[12] P. Miretzky and A. F. Cirelli, "Cr (VI) and Cr (III) removal from aqueous solution by raw and modified lignocellulosic materials: a review," Journal of Hazardous Materials, vol. 180, no. 1-3, pp. 1-19, 2010.

[13] C. J. Lin, S. L. Wang, P. M. Huang et al., "Chromate reduction by zero-valent $\mathrm{Al}$ metal as catalyzed by polyoxometalate," Water Research, vol. 43, no. 20, pp. 5015-5022, 2009.

[14] D. Reddithota, A. Yerramilli, and R. J. Krupadam, "Electrocoagulation: a cleaner method for treatment of Cr (VI) from electroplating industrial effluents," Indian Journal of Chemical Technology, vol. 14, pp. 140-245, 2007.

[15] M. Jobbágy and A. E. Regazzoni, "Anion-exchange equilibrium and phase segregation in hydrotalcite systems: intercalation of hexacyanoferrate (III) ions," The Journal of Physical Chemistry B, vol. 109, no. 1, pp. 389-393, 2005.

[16] Y. Zhao, P. Chen, B. Zhang et al., "Highly dispersed $\mathrm{TiO}_{6}$ units in a layered double hydroxide for water splitting," Chemistry-A European Journal, vol. 18, no. 38, pp. 11949-11958, 2012.

[17] L.-S. Zhong, J.-S. Hu, H.-P. Liang, A.-M. Cao, W.-G. Song, and L.-J. Wan, "Self-assembled 3D flowerlike iron oxide nanostructures and their application in water treatment," Advanced Materials, vol. 18, no. 18, pp. 2426-2431, 2006.

[18] S.-T. Zheng and G.-Y. Yang, "Recent advances in paramagnetic-TM-substituted polyoxometalates $(\mathrm{TM}=\mathrm{Mn}, \mathrm{Fe}, \mathrm{Co}$, $\mathrm{Ni}, \mathrm{Cu}), "$ Chemical Society Reviews, vol. 41, no. 22, pp. 7623-7646, 2012.

[19] P. Yin, D. Li, and T. Liu, "Solution behaviors and self-assembly of polyoxometalates as models of macroions and amphiphilic polyoxometalate-organic hybrids as novel surfactants," Chemical Society Reviews, vol. 41, no. 22, pp. 7368-7383, 2012.

[20] H. N. Miras, J. Yan, D.-L. Long, and L. Cronin, "Engineering polyoxometalates with emergent properties," Chemical Society Reviews, vol. 41, no. 22, pp. 7403-7430, 2012.

[21] S. Omwoma, C. T. Gore, Y. Ji, C. Hu, and Y.-F. Song, "Environmentally benign polyoxometalate materials," Coordination Chemistry Reviews, vol. 286, pp. 17-29, 2015.

[22] S. R. Bajpe, E. Breynaert, K. Robeyns et al., "Chromate-mediated one-step quantitative transformation of PW12 into P2W20 polyoxometalates," European Journal of Inorganic Chemistry, vol. 2012, no. 24, pp. 3852-3858, 2012.

[23] P. J. Domaille, G. Hervéa, and A. Téazéa, "Vanadium (V) substituted dodecatungstophosphates," in Inorganic Syntheses, John Wiley \& Sons, Hoboken, NJ, USA, 2007.

[24] M. Shao, F. Ning, J. Zhao, M. Wei, D. G. Evans, and X. Duan, "Preparation of $\mathrm{Fe}_{3} \mathrm{O}_{4} @ \mathrm{SiO}_{2} @$ layered double hydroxide coreshell microspheres for magnetic separation of proteins," Journal of the American Chemical Society, vol. 134, no. 2, pp. 1071-1077, 2012.

[25] L. Li, Y. Feng, Y. Li, W. Zhao, and J. Shi, " $\mathrm{Fe}_{3} \mathrm{O}_{4}$ core/layered double hydroxide shell nanocomposite: versatile magnetic matrix for anionic functional materials," Angewandte Chemie International Edition, vol. 48, no. 32, pp. 5888-5892, 2009.
[26] B.-I. Lee and S.-H. Byeon, "Highly enhanced photoluminescence of a rose-like hierarchical superstructure prepared by self-assembly of rare-earth hydroxocation nanosheets and polyoxomolybdate anions," Chemical Communications, vol. 47, no. 14, pp. 4093-4095, 2011.

[27] K.-H. Lee and S.-H. Byeon, "Extended members of the layered rare-earth hydroxide family, $\mathrm{RE}_{2}(\mathrm{OH}) \quad 5 \mathrm{NO}_{3} \cdot \mathrm{nH}_{2} \mathrm{O}$ $(\mathrm{RE}=\mathrm{Sm}, \mathrm{Eu}$, and $\mathrm{Gd})$ : synthesis and anion-exchange behavior," European Journal of Inorganic Chemistry, vol. 2009, no. 7, pp. 929-936, 2009.

[28] F. Geng, Y. Matsushita, R. Ma et al., "General synthesis and structural evolution of a layered family of $\mathrm{Ln}_{8}(\mathrm{OH}) 20 \mathrm{Cl} 4 \cdot \mathrm{nH} 2 \mathrm{O}$ ( $\mathrm{ln}=\mathrm{aDy}, \mathrm{Ho}, \mathrm{Er}, \mathrm{Tm}$, and Y)," Journal of the American Chemical Society, vol. 130, no. 48, pp. 16344-16350, 2008.

[29] EPA Method, Determination of Hexavalent Chromium in Drinking Water by Chromatography with Post-Column, United States Environmental Protection Agency, Washington, DC, USA, 2011, http://water.epa.gov/drink.

[30] S. D. Winslow, B. V. Pepich, J. J. Martin et al., "Statistical procedures for determination and verification of minimum reporting levels for drinking water methods," Environmental Science \& Technology, vol. 40, no. 1, pp. 281-288, 2006.

[31] T. Yamashita and P. Hayes, "Effect of curve fitting parameters on quantitative analysis of $\mathrm{Fe}_{0} .94 \mathrm{O}$ and $\mathrm{Fe}_{2} \mathrm{O}_{3}$ using XPS," Journal of Electron Spectroscopy and Related Phenomena, vol. 152, no. 1-2, pp. 6-11, 2006.

[32] X. Wang, W. Chen, and Y.-F. Song, "Directional self-assembly of exfoliated layered europium hydroxide nanosheets and $\mathrm{Na}_{9} \mathrm{EuW}_{10} \mathrm{O}_{36} \cdot 32 \mathrm{H} 2 \mathrm{O}$ for application in desulfurization," European Journal of Inorganic Chemistry, vol. 2014, no. 17, pp. 2779-2786, 2014.

[33] N. A. Spaldin, Magnetic Materials: Fundamentals and Device Applications, pp. 89-106, Cambridge University Press, Cambridge, UK, 2006.

[34] J. U. Oubagaranadin, N. Sathyamurthy, and Z. V. Murthy, "Evaluation of fuller's earth for the adsorption of mercury from aqueous solutions: a comparative study with activated carbon," Journal of Hazardous Materials, vol. 142, no. 1-2, pp. 165-174, 2007.

[35] M. Tuzen, A. Sari, D. Mendil, and M. Soylak, "Biosorptive removal of mercury (II) from aqueous solution using lichen (Xanthoparmelia conspersa) biomass: kinetic and equilibrium studies," Journal of Hazardous Materials, vol. 169, no. 1-3, pp. 263-270, 2009.

[36] S. Azizian, "Kinetic models of sorption: a theoretical analysis," Journal of Colloid and Interface Science, vol. 276, no. 1, pp. 47-52, 2004.

[37] H. K. Boparai, M. Joseph, and D. M. O'Carroll, “Kinetics and thermodynamics of cadmium ion removal by adsorption onto nano zerovalent iron particles," Journal of Hazardous Materials, vol. 186, no. 1, pp. 458-465, 2011.

[38] W. Plazinski, W. Rudzinski, and A. Plazinska, "Theoretical models of sorption kinetics including a surface reaction mechanism: a review," Advances in Colloid and Interface Science, vol. 152, no. 1-2, pp. 2-13, 2009.

[39] H. N. Tran, S.-J. You, A. Hosseini-Bandegharaei, and H.-P. Chao, "Mistakes and inconsistencies regarding adsorption of contaminants from aqueous solutions: a critical review," Water Research, vol. 120, pp. 88-116, 2017.

[40] B. Sels, D. D. Vos, M. Buntinx, F. Pierard, A. Kirsch-De Mesmaeker, and P. Jacobs, "Layered double hydroxides exchanged with tungstate as biomimetic catalysts for mild oxidative bromination," Nature, vol. 400, no. 6747, pp. 855857, 1999. 